Ronnived by 0STI

FEB 061989

\title{
The DOE Thermal Regimes Drilling Program through 1987
}

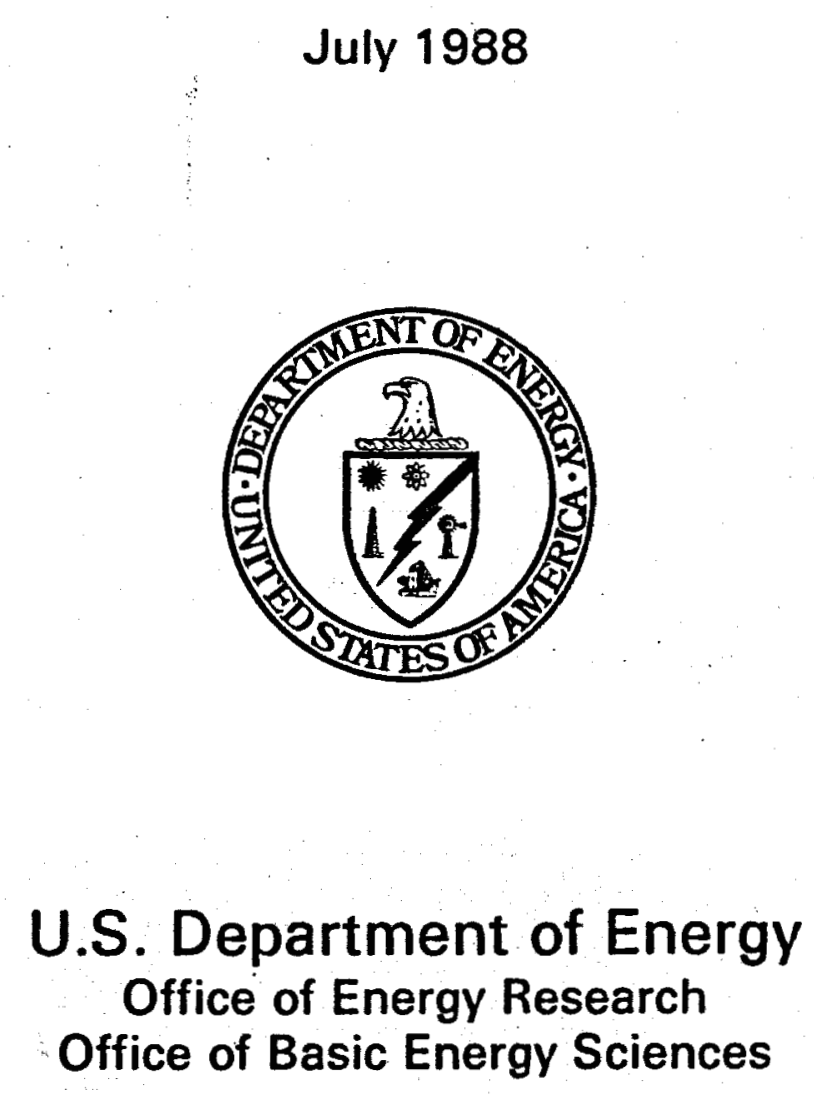




\section{Summary}

\section{H. Wollenberg}

In response to strong endorsement from the scientific community, in the form of a report by the Continental Scientific Drilling Committee of the National Academy of Sciences (CSDC, 1984), the Office of Basic Energy Sciences of the DOE undertook a program of investigations of young magmatic intrusions and their associated thermal systems. To date, the effort has encompassed the first phases of a program to investigate the roots of active hydrothermal systems and has also investigated the thermal, chemical, and mechanical behavior of geologically recent (less than 600 years) magmatic extrusions. Shallow to intermediate-depth holes have been drilled and cored into hydrothermal systems in the silicic Valles and Long Valley calderas and at the crustal spreading center of the Salton Trough. These projects are briefly summarized here and are covered in greater detail in the accompanying appendices.

\section{THE LONG VALLEY-INYO PROJECT}

To investigate the thermal, chemical, and mechanical behavior of magma during its ascent toward the surface in an igneous system young enough so that it is essentially unchanged subsequent to its emplacement, four holes were continuously cored in the Inyo chain of rhyolitic domes and flows in Long Valley, California (Fig. 1 in Appendix 1). Three holes were drilled in or adjacent to the -600 -year-old rhyolitic Obsidian Dome north of the Long Valley caldera, and one was drilled near the phreatic Inyo Crater, in the caldera fill. The first two were drilled in 1984 and 1985 on the dome, the first hole penetrating the side of the obsidian carapace and continuing into the underlying Tertiary andesite. The second hole intersected and passed through the dome's vent and into Sierran granitic rock. The third hole, drilled in 1985, sampled the rhyolitic dike that cuts Sierran granite and that fed the dome through a conduit. The dike also connects the dome with its neighbor to the south.

The first three Inyo holes investigated behavior of magma in the relatively "dry" environment of basement or pre-caldera rocks. Results indicated that ascending magma is a chemically open system, that degassing of magma occurs in a two-stage process, and that water loss is as important as heat loss in the formation of glass from magma. To compare behavior of the same magma in the contrasting environment of caldera fill, the fourth Inyo hole, cored in 1987, was to intersect the same dike or dike system further south where it intruded fill of the Long Valley caldera. Surprisingly, the hole intersected a brecciated zone, containing caldera-moat basalt, at the expected position of the dike beneath the Inyo crater lake, then passed directly into metamorphic rock of the Sierran basement without intersecting any more caldera fill. Comparison of rock units in Inyo 4 with those in Unocal's $44-16$ hole, less than $1 \mathrm{~km}$ to the east, indicates 
that a major fault of the caldera's ring fracture system lies between the two holes. This most recent Inyo drilling provides a view of intrusive structures beneath a young phreatic volcano and will help develop an understanding of the mechanisms of magma-water-wallrock interaction that cause phreatic events.

Continuous coring, with better than $90 \%$ recovery, of the one vertical and three inclined holes totaled $2170 \mathrm{~m}$, at a cost of $\$ 830,000$.

\section{LONG VALLEY HYDROTHERMAL DRILLING PROJECT}

As part of the investigation of the hydrothermal system of the Long Valley caldera, a hole was continuously cored in 1986 to a depth of $715 \mathrm{~m}$ in caldera fill in the caldera's west moat. The objective of the hole, situated $2 \mathrm{~km}$ north of the town of Mammoth Lakes, was to investigate the presence and thermal and chemical character of hydrothermal fluid and hydrothermally altered rocks in order to better understand the nature of the hydrothermal system west of its previously known occurrences. In this respect, the hole was necessary to provide information for subsequent siting of deeper holes to study the roots of the hydrothermal system and its heat source. The hole also provided information about the energy resource potential for direct utilization of geothermal fluids by the local community, and, for that reason, partial funding for drilling was provided by the California Energy Commission and Mono County. Close collaboration on drilling and subsequent logging and sampling was maintained with the USGS.

Initial findings indicate that a temperature of $202^{\circ} \mathrm{C}$ is reached at relatively shallow depth $(335 \mathrm{~m})$ in caldera fill, below which conditions are nearly isothermal to the hole's total depth. At this location, permeability in the Bishop Tuff is provided by nearly vertical open fractures. Isotope ratios indicate that a component of the hydrothermal fluid circulates in the sub-caldera Sierran basement rock. The concept of west-to-east flow in the hydrothermal system is confirmed, and the principal heat source for the system most probably underlies the west moat. A potential geothermal resource was identified for Mammoth Lakes.

Coring was continuous, with recovery exceeding $90 \%$. The cost of drilling the $715-\mathrm{m}$ hole totaled $\$ 184,000$.

\section{THE VALLES CALDERA PROJECT}

As part of a long-term program to investigate the Valles Caldera, two holes have been cored to date, one to intersect the caldera's hydrothermal outflow plume outside the caldera, the second to penetrate the vapor-dominated zone and its interface with the underlying hot-water system within the caldera. The first hole, VC-1, was cored to $856 \mathrm{~m}$, penetrating the overlying moat volcanic units but predominantly encountering hydrothermally altered pre-caldera Paleozoic sedimentary rock that borders the caldera on the south. The second hole, VC-2A, cored to $528 \mathrm{~m}$, sampled the vapor zone and the upper portion of the 
liquid-dominated zone, which contains sub-ore-grade molybdenite mineralization. Hole VC-1 showed that the hydrothermal outflow plume is present and consists of fluid components from the caldera mixed with near-surface components along its flow path. The youngest moat volcanics are unexpectedly thick and represent a magma batch separate from the earlier caldera-forming magma system. The pre-caldera rocks in the outflow plume are mineralized and brecciated and contain a complex record of hydrothermal activity resulting from 1 million years of lateral flow.

Results of the VC-2A hole indicate that the vapor zone formed about 0.5 million years ago and that the interface between the vapor- and liquid-dominated zones is not sharp but is instead a zone up to $150 \mathrm{~m}$ thick. Rock units have been rotated from 30 to $45^{\circ}$ due to structural resurgence in the caldera. Sub-oregrade molybdenite mineralization ( $<1.1$ million years old and up to 0.6 weight $\% \mathrm{MoS}_{2}$ ) at depths from 25 to $125 \mathrm{~m}$ is analogous to ore deposits in "fossil" caldera systems. The molybdenite deposit formed from hydrothermal fluids of composition similar to those circulating in the caldera today.

To date, continuous coring in the Valles project totals $1384 \mathrm{~m}$, with core recovery better than $90 \%$. Drilling costs total $\$ 490,000$.

\section{THE SALTON SEA SHALLOW DRILLING PROJECT}

The project was formulated to determine the shape and lateral extent of the thermal anomaly at the south end of the Salton Sea and to incorporate this configuration into models of the evolution of the magma-hydrothermal system and its role in the process of crustal rifting of the Salton Trough. To accomplish this, in 1985, 19 holes $80 \mathrm{~m}$ deep were drilled offshore north and west of the rhyolitic domes that border the south end of the Salton Sea. Drilling was done with a truck-mounted rig on a barge. The holes were cased, filled with sea water, and temperature profiles obtained for heat-flow determinations.

Initial findings indicate that the shape of the region of high thermal gradients is not centered on the rhyolitic domes, as was originally thought, but is offset to the south. There is a narrow transition zone, only $2.4 \mathrm{~km}$ wide, between locations with high thermal gradients (to $0.85^{\circ} \mathrm{C} / \mathrm{m}$ ) and those with near-normal gradients $\left(0.09^{\circ} \mathrm{C} / \mathrm{m}\right)$. The heat flow in the central part of the thermal anomaly is greater than $600 \mathrm{~mW} / \mathrm{m}^{2}$, with two smaller areas having twice that heat flow; This project and the deep $(-3.22 \mathrm{~km})$ Salton Sea Scientific Drilling Project complement each other in that a combination of areal and depth coverage provides a three-dimensional picture of an intensive crustal thermal anomaly. The project points out the effectiveness of a number of shallow holes in delimiting the areal extent of a complex hydrothermal anomaly.

Drilling totaled $-1500 \mathrm{~m}$, with a total cost of $\$ 290,000$. 


\section{THE SALTON SEA SCIENTIFIC DRILLING PROJECT (SSSDP)}

In late 1985 and into 1986, a research hole was drilled to a depth of $3.22 \mathrm{~km}$ near the Salton Sea in the Imperial Valley of southern Califomia. Funding for drilling and related activities was primarily from DOE's Geothermal Technology Division; significant support for scientific activities associated with the hole was also provided by the Office of Basic Energy Sciences. The project's objective was to thoroughly investigate the physical and chemical processes of a high-temperature, high-salinity magmatically driven hydrothermal system. To accomplish this the hole was drilled into the Salton Sea geothermal system, where temperatures were known to exceed $300^{\circ} \mathrm{C}$ and salinities to exceed $20 \%$ of total dissolved solids (TDS). In this hole temperatures of $355^{\circ} \mathrm{C}$ were reached and salinities exceeded $25 \%$ TDS. Though the majority of the hole was rotary drilled, over $0.2 \mathrm{~km}$ of core was recovered, encompassing a range of lithology from unconsolidated lakebed sediments to metamorphosed rock of lower amphibolite facies, containing some ore minerals. Igneous rocks intersected included silicic tuff at a depth of $1.7 \mathrm{~km}$, probably from a source outside the Salton Trough, and diabasic sills at $\sim 2.9 \mathrm{~km}$ that are probably related to the basaltic heat source for the hydrothermal system.

Two flow tests produced high-salinity brines containing metal-rich salts. The first test was done in a zone at $1.865 \mathrm{~km}$; the second, after the hole had reached total depth, was done in various flow zones at depths of $1.86,2.01,2.68$, and $3.19 \mathrm{~km}$. Flow rates to 350 tonnes per hour demonstrated the commercial potential of the deep portion of the geothermal field.

The hole provided the opportunity to use a number of downhole logging devices, vertical seismic profiling, and fluid samplers in a high-temperature environment. The mixed successes of these activities provide a good assessment of the state of the art of high-temperature downhole operations. Difficulties were encountered after cessation of drilling when a 7-inch-diameter liner parted and could not be retrieved. Attempts to sidetrack the hole around the fallen liner and redrill were abandoned at $2188 \mathrm{~m}$ in August 1987.

The budget for drilling and completion of the hole, including engineering and management, totaled $\$ 6.7$ million, of which $\$ 2.65$ million for scientific studies was allocated jointly by the USGS, NSF, and DOE. Together with the shallow drilling project described below, the SSSDP helped to develop a threedimensional picture of this important hydrothermal system.

\section{LESSONS LEARNED}

In summary, through 1987 coring has exceeded $4 \mathrm{~km}$ in the DOE/BES-sponsored thermal regimes drilling program, with core recovery well in excess of $90 \%$. Core hole costs have totaled $\$ 1.5$ million (an average cost of $\sim \$ 350 / \mathrm{m}$ ). Together with the Salton Sea shallow drilling project (but excluding the deep Salton Sea hole), drilling has totaled nearly $5.8 \mathrm{~km}$ at a total cost of $\$ 1.8$ million. 
The program has demonstrated the great scientific return of relatively shallow drilling, at modest cost, to study magmatic processes and hydrothermal systems. Difficulties were encountered in some of the projects: twist-offs in two of the inclined Inyo holes, loss of the bottom half of the Long Valley hydrothermal hole for continued access, the loss of a liner in the deep Salton Sea hole, and the inability to drill all of the planned shallow Salton Sea holes due to bad weather, but the principal scientific goals of each of the projects were achieved. In each case, valuable lessons were leamed about coring procedures, especially in the relatively high-temperature environments of the hydrothermal systems, and also about on-site decision making. These have influenced the planning, cost estimates, and conduct of the next phase of the CSD thermal regimes program: deeper exploration (to $-2 \mathrm{~km}$ ) of caldera-hydrothermal environments, ultimately to study the roots of the hydrothermal systems at depths on the order of $5 \mathrm{~km}$, and investigation of more recent magmatic manifestations that still contain significant magmatic heat, exemplified by the planned Katmai project and perhaps studies of volcanoes of the Cascades Range.

The growth and development of expertise of the supporting Geosciences Research Drilling Office (GRDO) and Curatorial Office, concomitant with the drilling projects, has made these offices invaluable in the planning and conduct of the projects as well as in post-drilling activities.

\section{CONTINUING WORK}

Projects planned for the late 1980 s and early 1990 s include a $-2-\mathrm{km}$-deep exploration of the active hydrothermal system of the Valles Caldera. In 1988 a continuously cored hole will penetrate the vaporphase zone in caldera fill, will extend into saturated volcanic rocks through Paleozoic sedimentary units, and will bottom in Precambrian crystalline rocks at temperatures in the $300^{\circ} \mathrm{C}$ range. There is the probability that this hole will encounter deeper manifestations of the molybdenite mineralizations found in nearby hole VC-2A. Concurrently, the early stages of a project to investigate, by drilling, the cooling thermal regime triggered by the 1912 Katmai eruption will begin in 1988. In subsequent field seasons, two to three holes, up to $1.2 \mathrm{~km}$ deep, will core the 1912 eruptive vent and its walls, and one hole will core the associated ash flow sheet. Also in 1988, DOE's Geothermal Technology Division will begin drilling a hole in the Long Valley caldera to investigate the possibility of energy recovery from magma. The target depth for this rotary-drilled hole is $-5.5 \mathrm{~km}$, and it is hoped that at or near that depth the rock temperature reaches $500^{\circ} \mathrm{C}$. This hole will penetrate caldera fill and will extend well into Sierra Nevada basement rocks comprising Paleozoic metasediments, Mesozoic granitics, and possibly young intrusive rock associated with post-caldera eruptives. The hole will be drilled in stages over the next 4 years. Though it is primarily for engineering studies, scientific activities associated with the magma-energy hole will provide the opportunity for investigation of the geophysical, hydrological, and geochemical settings of the deep sub-caldera environment, which may include the transition zone between the roots of a hydrothermal system and underlying magma. 


\section{REFERENCE}

CSDC, 1984, A national drilling program to study the roots of active hydrothermal systems related to young magmatic intrusions: National Academy Press, Washington, DC. 


\section{Appendices}

1. Summary of the Inyo Drilling Project

2. Summary of Long Valley Hydrothermal Drilling

3. Summary of the Valles Caldera Scientific Drilling Program

4. Summary of Salton Sea Shallow Drilling Program

5. The Salton Sea Scientific Drilling Project 


.

? 


\title{
Appendix 1
}

\section{Summary of the Inyo Drilling Project}

\author{
J. Eichelberger \\ Sandia National Laboratories
}

\section{OBJECTIVES AND APPROACH}

The general goal of research drilling in the Inyo Domes volcanic chain of eastem California was to improve understanding of the thermal, chemical, and mechanical behavior of magma during its ascent toward the surface. The approach was to sample, by wireline diamond coring techniques, the subsurface portions of an igneous system that is so young as to be essentially unchanged by geologic events subsequent to its emplacement. In particular, this approach permits determination of the distribution of retained magmatic volatiles before these components are redistributed by hydration and alteration, and establishment of the relationship between eruptive and intrusive events before delicate tephra layers and structures are removed by erosion. Under favorable conditions, such an approach would permit measurement of the distribution of magmatic heat in an actively cooling intrusion. The sampling of intrusive structures by coring also provides information about subsurface features, such as fragile vent breccias, that would not survive exposure of such systems by erosion.

The Inyo chain was chosen for a drilling investigation because (1) it is the youngest of the rhyolitic volcanoes in the contiguous United States and hence the youngest of easily accessible rhyolitic systems, (2) its surface-accessible portions had been well characterized, and (3) a well-defined concept had been developed concerning its subsurface configuration. That concept, which was based on evidence that the linear array of vents had been active contemporaneously 600 years ago, was that the eruptions and accompanying surface formation were the surface manifestation of the emplacement at shallow depth of a rhyolite dike. It was suggested that such intrusive feeders were the general case for thyolite volcanoes, because of the mechanical facility of intruding magma as a fracture-filling sheet rather than as a finger. The geometry of the hypothesized target lent itself to testing by drilling. Moreover, because the hypothesized dike crossed the structural boundary of the Long Valley caldera, the opportunity existed to compare the behavior of the same magma in the contrasting geologic environments of caldera fill and Sierran basement. A program of drilling (Fig. 1) was laid out that would sample the far-vent (Inyo-1) and near-vent (Inyo-2) sections of the largest of the lava extrusions, vented (Inyo-2, conduit) and unvented (Inyo-3) portions of the dike outside the caldera, and the dike inside the caldera (Inyo-4). Specific objectives were to compare the structure, chemical zonation, crystallinity, and volatile content of these igneous units in relation to the large variety of conditions in which they were emplaced, and to determine the relationship of eruption products to individual intrusive units and events. 


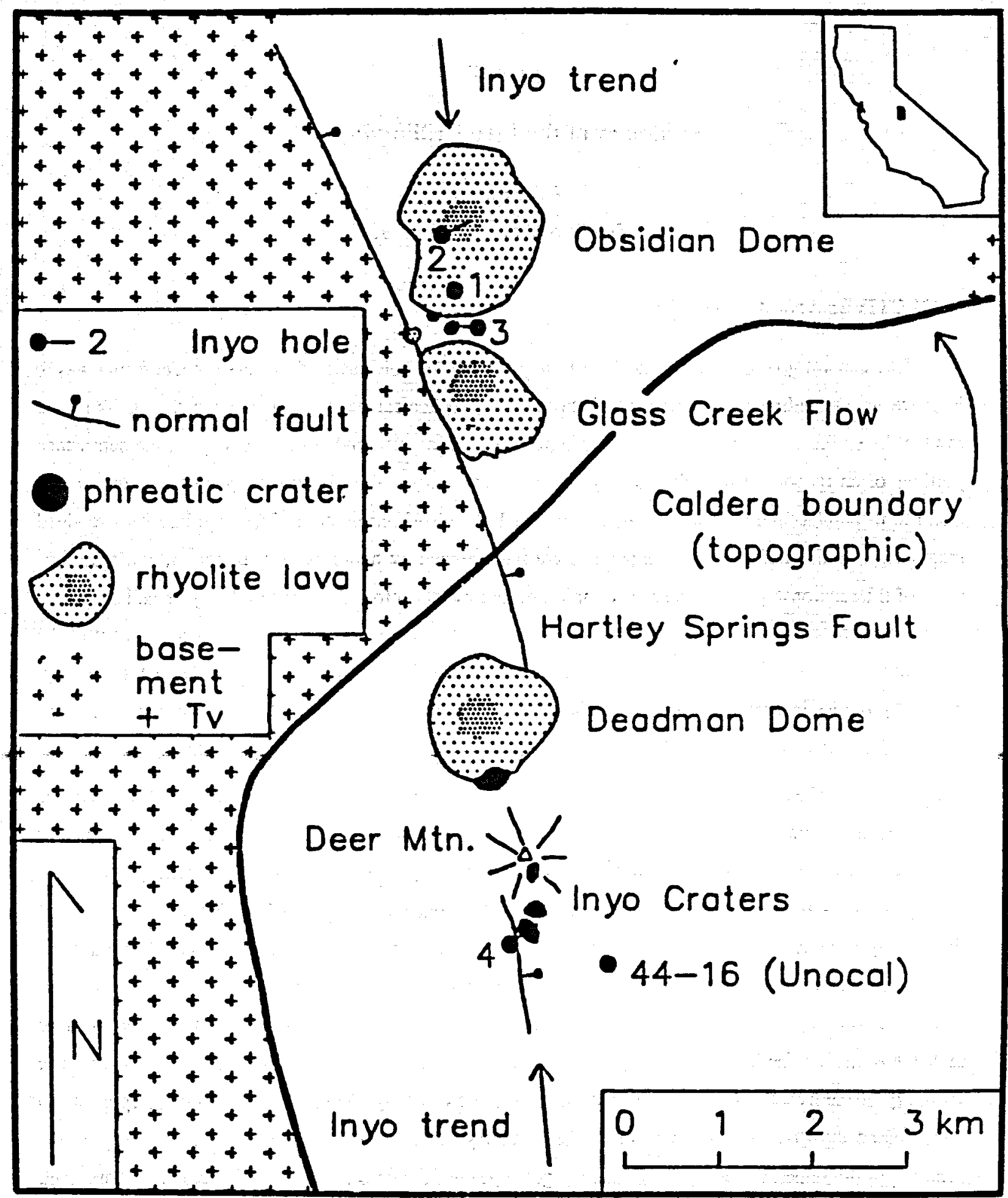

XBL $886-2364$

Figure 1. Inyo project drilling sequence and locations of holes. 


\section{FINDINGS}

Figures 2 and 3 display the general results of the four core holes. Subsurface structures encountered in the Obsidian Dome area were remarkably close to predrilling predictions, although there were surprises in the distribution of porosity, volatiles, and crystallinity, and in the existence of strong chemical gradients within units. In contrast, results at South Inyo Crater differed dramatically from a predrilling model that took theory, careful surface observations, and the previous drilling results into account.

The Obsidian Dome thyolite lava flow was found to be about $50 \mathrm{~m}$ thick at both sample points, with a microcrystalline interior, 20-m-thick glassy carapace, and 10-m-thick glassy base. Obsidian is restricted to the distal portion of the flow; the entire near-vent section contains significant primary porosity (vesicles). Volatile contents throughout the sections are consistent with degassing to atmospheric pressure. The flow was fed through a conduit that is $30 \mathrm{~m}$ wide at $400-500 \mathrm{~m}$ depth. This feeder developed within a zone of tephra-related vent breccia and smaller intrusions that is $50 \mathrm{~m}$ wide. The conduit appears to be an enlarged portion of a simple dike that is $6 \mathrm{~m}$ wide at $600 \mathrm{~m}$ depth, $1 \mathrm{~km}$ south of the Obsidian Dome vent. In contrast to the lava flow, the intrusive portion of the system is wholly crystalline except for $\leq 10-\mathrm{cm}$ thick glassy margins on the section through the unvented portion of the dike. The flow was found to have a mafic-downward zonation, from thyolite to rhyodacite, that matches a radial-outward zonation in the conduit. The unvented portion of the dike is chemically more uniform and matches a portion of the tephra eruption; hence it is believed to have been emplaced early in the eruptive episode, during the explosive phase. No thermal anomaly clearly attributable to the intrusion was found.

Inyo-3 had encountered a sizable thyolitic dike beneath an area of small phreatic craters and no discernable surface deformation. In contrast, the portion of the Inyo chain within Long Valley caldera that was active 600 years ago is characterized by much larger phreatic craters and spectacular surface fractures. Hence, it was postulated that Inyo-4 would intersect a silicic dike much larger than the one intersected by Inyo-3. Although Inyo-4 closely followed the planned trajectory across the Inyo trend and directly under the largest of the phreatic craters, it encountered no young silicic intrusion. Instead, it encountered a 16$m$-wide breccia zone, the center of which is rich in pillow-like masses of caldera-moat basalt. The hole encountered basement much shallower and temperabures much lower than a Unocal well $900 \mathrm{~m}$ to the southeast.

\section{SCIENTIFIC IMPLICATIONS — SHORT TERM}

Results from drilling in the northern portion of the chain confirmed the hypothesized close relationship between shallow dike emplacement and the Inyo lava dome eruptions. Evidence from volatile distribution for the close approach of magma to chemical equilibrium at locally controlled lithostatic pressure indicated that ascending magma is a chemically open system. A model for porous-flow degassing of 


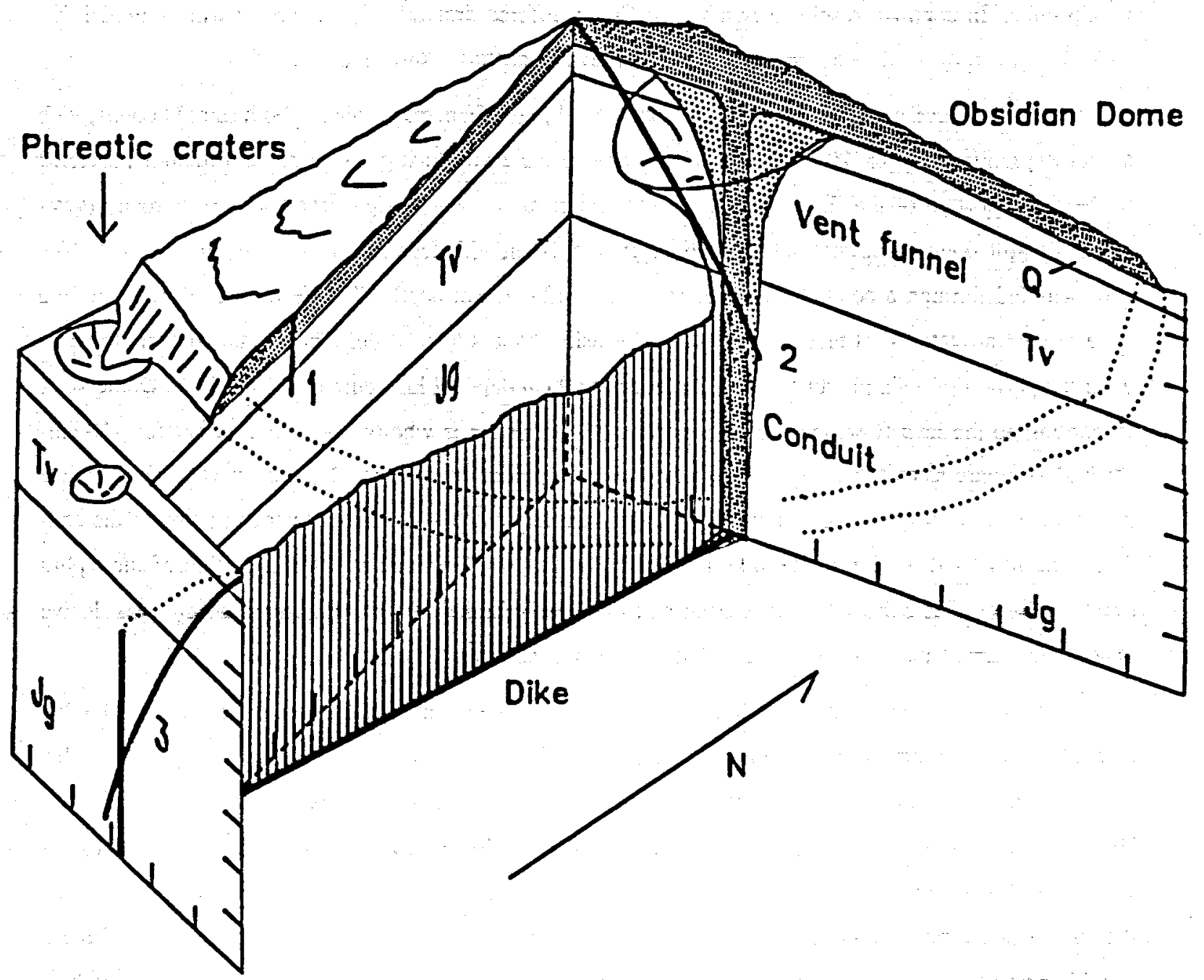

XBL $886-2365$

Figure 2. Cutaway section showing Inyo holes 1, 2, and 3, penetrating the flow, vent, and dike, respectively. 
magma was developed to explain this behavior and was based upon physical and geometrical constraints obtained from the drilling observations. An implication of the model is that enuptive behavior is strongly influenced by permeability of the shallow intrusive environment. Analysis of crystalline and glassy rocks at multiple depths permitted reconstruction of the degassing history and led to the conclusion that degassing is a two-stage process, with loss of water-rich vapor during isothermal decompression, and loss of chlorine-rich aqueous vapor during isobaric second boiling. Distribution of crystalline and glassy rocks within the system indicates that water loss plays as great a role as heat loss in "quenching" magma to glass. Chemical zonation of the system reflects a mafic to silicic sequence of magma emplacement during dome extrusion that apparently repeated a similar sequence during the tephra enuption. This may have resulted from an inversion of reservoir zonation during withdrawal, or a temporary, unstable zonation of the magma reservoir related to a mixing event. Much of the chemical variation can be explained by mixing with basaltic magma. This compositional problem remains unsolved.

Because drilling at South Inyo Crater did not intersect a dike comparable in composition to that beneath Obsidian Dome, it was not possible to carry out the comparison of magmatic behavior in the contrasting caldera and basement environments. However, the core provides the first view of intrusive structures beneath a young phreatic volcano and is now under study by a variety of techniques in order to understand the mechanisms of magma-water-wallrock interaction that give rise to phreatic events. Drilling also constrained the position of a major portion of the structural boundary of the caldera, suggesting that much of the western moat is a cold, shallow shelf. The problem posed by surface extension well in excess of intrusion width is unsolved.

\section{SCIENTIFIC IMPLICATIONS — LONG TERM}

The most basic result of Inyo drilling is an improved understanding of the geometry of silicic systems. While results, at least for the northern drilling, may seem "reasonable" or "unremarkable," it should be recalled that prior to drilling there was great skepticism as to whether these structures could be intersected, and there was two orders of magnitude variation in the postulated widths of the intrusion. This variation arose from the uncertainty in tying modem volcanoes to dissected fossil analogs. The results of Inyo drilling should lead to more realistic interpretations of the subsurface structures of modern volcanoes. Such realism is essential to proper understanding of cooling, degassing, and hydrothermal circulation in the subvolcanic regime.

The unexpectedly complex chemical zonation of the small-volume Obsidian Dome system has led to recognition of similar patterns of zonation elsewhere. The zonation was concealed at Obsidian Dome because the homogeneous last-erupted magma comprises most of the flow surface. We may find that this is a common feature of small-volume systems and records a quite different stage of magmatic evolution 
from that recorded in zoned tuff sheets.

Evidence for open-system behavior of ascending silicic magma and of quenching by water loss rather than by cooling should motivate a reexamination of the factors that lead to explosive vs. nonexplosive eruptions, and of the interpretation of the composition and phase relations of silicic lavas.

Drilling at Inyo Domes was a logical early step in the use of the drill as a research tool in the study of magmatic processes. At the time the project was developed, much of the discussion concerning drilling to solve magmatic problems centered on very deep holes to large magma chambers. Such drilling is far off for both budgetary and technological reasons. Drilling at Inyo showed that small igneous targets, undetectable by surface geophysical techniques, could be intersected by carefully oriented holes, and that there was scientific value in considering shallow magmatic processes. The logical next steps are to sample systems that retain considerable magmatic heat, and to extend the depth of exploration of such systems. While I believe that Katmai is the best choice for the next step, other attractive possibilities exist, particularly in the Cascade Range. Interesting igneous targets at shallow to moderate depth in the Inyo/Mono chain have by no means been exhausted. The advantage of a gradual approach to the magmatic environment is that it reduces the technological steps, and the no less important steps in growth of scientific concepts (I believe our view of magmatic processes is still crude and speculative), to manageable size. It would be a mistake, in my view, to restrict thermal-regimes drilling to hydrothermal systems and hope that someday we will push through them into magma. We should have a parallel course of pushing hotter and deeper into young intrusions. I hope that Inyo has laid the conceptual groundwork for such a course.

\section{DRILLING PROCEDURES}

Drilling the Inyo holes utilized standard wire-line diamond coring procedures. No special techniques were required. Costs of the holes are presented in Table 1. Most problems arose from the difficulty of drilling slanted holes in highly fragmental formations. Inyo-1 was the simplest, being short and vertical, and was drilled in a 12-hour-a-day operation by Boyles Brothers of Reno, Nevada. The only significant problem was that the drill string became stuck in unconsolidated Bishop Tuff. The three later holes were slanted and were drilled by Tonto of Salt Lake City, Utah. Inyo-2 twisted off at about $1200 \mathrm{ft}$, apparently

Table 1. Summary of Inyo drill holes.

\begin{tabular}{cccc}
\hline Hole No. & Initial dip & Slant depth (ft) & $\frac{\text { Cost (k\$) }}{30}$ \\
\hline 1 & $90^{\circ}$ & 500 & 30 \\
2 & $55^{\circ}$ & 2046 & 200 \\
3 & $54^{\circ}$ & 2719 & 200 \\
4 & $67^{\circ}$ & 2825 & 400 \\
\hline
\end{tabular}


due to both the hard, fractured character of the formation (basalt) and inattention of the driller. Inyo-3 twisted off at a similar depth and for similar reasons. Because of the position of the break, it was necessary to wedge the hole, but the drill string became stuck during an extended wedge-orientation maneuver. This necessitated cutting off $400 \mathrm{ft}$ of drill string and conducting a second wedge job, which was successful. Inyo-3 deviated very severely, both in dip and azimuth.

Inyo-4 proceeded slowly but smoothly. The hole deviated the least of the three slanted holes, and the drill did not twist off or become seriously stuck. Geologic conditions were probably more severe in the case of Inyo-4. The improvement seems attributable to GRDO's insistence on a highly experienced drilling crew, and the conservative manner in which the drilling was conducted.

\section{RETROSPECTIVE LOOK}

The conduct of the DOE Continental Scientific Drilling Program (CSDP) has evolved greatly during the course of this project. For the most part these changes represent growing and maturing, but some dangers exist. The first drilling was a result of a short proposal written by representatives from LANL, LBL, LLNL, and SNL. Not being able to agree on a single hole, three very modest undertakings at three sites, including Obsidian Dome, were proposed. As it turned out, the budgets greatly exceeded the projects in modesty. Drilling and core management was as much a responsibility to the PIs as of the nascent GRDO and Core Curation Offices.

The second Inyo proposal round, which involved Inyo-3 but was implemented in the same operation as Inyo-2, was put forth by a consortium of 18 investigators from 9 institutions. In the interest of planning, the document included five years of drilling, which was, in retrospect, overly grand. The problem with such long-term planning is that it cannot take into account the surprises that near-term drilling produces.

The third and most recent Inyo proposal was submitted by a consortium of 42 investigators from 13 institutions. The document was greeted with some dismay in Washington, in view of its ponderous size. Nevertheless, it represented an honest attempt by the PIs to present a complete and well-integrated scientific package, and to respond to the excitement and desire for involvement that the Inyo drilling had generated in the scientific community.

Reality has dictated that future proposals be more streamlined. However, it would be a mistake to delete scientific investigations from drilling proposals entirely for two reasons. First, the scientific investigations are the rationale for scientific drilling, and are the primary means of judging a drilling proposal. Without a complete statement of necessary scientific investigations in the document, the proposed drilling cannot be adequately judged. It is not enough to vaguely state what could be done and learned. The techniques, people, and costs must be spelled out. Second, unless scientists are actively involved in designing the experiment from the start, they are unlikely to be enthusiastic and committed later. If science is to be 
tacked on after a drilling project is defined, we are in danger of calling a party and having no one come.

The growth of the capabilities and responsibilities of the drilling and curation offices has relieved considerable burden from the PIs and increased their scientific productivity. I think that the current state is near balance. However, the possible options of excluding scientists from the drill site and duplicating or supplanting core loggers who are project scientists with "professionals" are dangerous, because they divorce the scientists from the scientific process, which scientific drilling is.

\section{PUBLICATIONS RESULTING FROM THE INYO DRILLNG PROJECT}

Blake, S., and J. H. Fink, The dynamics of magma withdrawal from a density-stratified dike: Earth Planet. Sci. Lett., 85, 516-524, 1987.

Eichelberger, J. C., C. R. Carrigan, H. R. Westrich, and R. H. Price, Non-explosive silicic volcanism: Nature, 323, 598-602, 1986.

Eichelberger, J. C., P. C. Lysne, and L. W. Younker, Research drilling at Inyo Domes, Long Valley Caldera, Califomia: Eos, 65, 721, 723-725, 1984.

Eichelberger, J. C., P. C. Lysne, C. D. Miller, and L. W. Younker, Research drilling at Inyo Domes, California: 1984 results: Eos, 66, 186-187, 1985.

Eichelberger, J. C., H. W. Stockman, T. A. Vogel, H. R. Westrich, and C. D. Miller, Intrusion and eruption at Obsidian Dome, Inyo Domes, California: To be submitted to J. Geophys. Res.

Eichelberger, J. C., L. W. Younker, T. A. Vogel, and C. D. Miller, Structure and stratigraphy beneath a young phreatic vent: South Inyo Crater, Long Valley Caldera, California: To be submitted to J. Geophys. Res.

Fink, J.H., Geometry of silicic dikes beneath the Inyo Domes, Califomia: J. Geophys. Res. 90, 11, 127 $134,1985$.

Fink, J. H., and C. R. Manley, Origin of pumiceous and glassy textures in myolite flows and domes: Geol. Soc. Amer. Spec. Paper 212, 77-88, 1987.

Heiken, G., K. Wohletz, and J. C. Eichelberger, Fracture fillings and intrusive pyroclasts, Inyo Domes, California: J. Geophys. Res., in press.

Manley, C. R., and J. H. Fink, Internal textures of thyolite flows as revealed by research drilling: Geology, 15, 549-552, 1987.

"Mastin, L. G., and D. D. Pollard, Surface deformation and shallow dike intrusion processes at Inyo Craters, Long Valley, California: J. Geophys. Res., in press.

${ }^{\dagger}$ McConnell, V. S., and J. C. Eichelberger, Volcanic eruptions and research drilling in the Inyo Domes chain, California: Booklet published by Sandia National Laboratories, Albuquerque, NM, 1987.

"Miller, C. D., Holocene eruptions at the Inyo volcanic chain, California -Implications for possible eruptions in the Long Valley Caldera: Geology, 13, 14-17, 1985.

Reches, Z., and J. H. Fink, The mechanism of intrusion of the Inyo dike, Long Valley Caldera, California: J. Geophys. Res., in press.

Swanson, S. E., M. T. Naney, H. R. Westrich, and J. C. Eichelberger, Crystallization history of Obsidian Dome, Inyo Domes, California: Bull. Volcanol., in press.

"Taylor, B. E., J. C. Eichelberger, and H. R. Westrich, Hydrogen isotopic evidence of rhyolite magma degassing during shallow intrusion and eruption: Nature, 306, 541-545, 1983.

Vogel, T. A., L. W. Younker, and B. C. Schuraytz, Constraints on magma ascent, emplacement, and eruption: Geochemical and geological data from drill-core samples at Obsidian Dome, Inyo Chain, Cali-

Predrilling study.

Booklet prepared for visitors to Inyo National Forest. 
formia: Geology, 15, 405-408, 1987.

Westrich, H. R., H. W. Stockman, and J. C. Eichelberger, Degassing of thyolitic magma during ascent and emplacement: J. Geophys. Res., in press.

Younker, L. W., J. C. Eichelberger, P. W. Kasameyer, R. L. Newmark, and T. A. Vogel, Results from shallow research drilling at Inyo Domes, Long Valley Caldera, California and the Salton Sea geothermal field, Salton Trough, Califomia: Proceedings of the Third International Symposium on Observation of the Continental Crust through Drilling, in press. 


\title{
Appendix 2
}

\section{Summary of Long Valley Hydrothermal Drilling Project:}

\author{
Hole RD0.8 (Shady Rest)
}

\author{
H. Wollenberg \\ Lawrence Berkeley Laboratory
}

\section{OBJECTIVES}

The objectives of this drilling project were (1) to explore the hydrothermal system of the west moat of the Long Valley caldera, west of the surface occurrences at Casa Diablo Hot Springs; and (2) to investigate the presence, and thermal and chemical character, of geothermal fluid in the Early Rhyolite and Bishop Tuff, from the standpoint of both understanding the present-day hydrothermal system and investigating the energy-resource potential for direct utilization of geothermal water by the community of Mammoth Lakes.

\section{ACTIVITIES}

Hole RDO-8 was cored to a depth of $715 \mathrm{~m}$, near the Shady Rest Campground, $-2 \mathrm{~km}$ north of Mammoth Lakes.

\section{FINDINGS}

Temperatures in post-caldera deposits increase rapidly with depth to $202^{\circ} \mathrm{C}$ at $335 \mathrm{~m}$ in Early Rhyolite, then are nearly isothermal into the Bishop Tuff to total depth (Fig. 1). Permeability in the Bishop Tuff is provided by open, calcite-quartz-pyrite-lined fractures. Calcite fluid-inclusion temperatures are compatible with measured temperatures. Strontium and carbon isotope ratios indicate that a component of the geothermal fluid has circulated in the sub-caldera Sierran metamorphic basement rock. The depth to the Bishop Tuff is the shallowest and temperatures are among the highest in holes drilled in the caldera $A$ potential geothermal resource has been identified for the community of Mammoth Lakes. Chemical analyses, stable-isotope ratios, and temperatures indicate that the Shady Rest fluid supplies the Casa Diablo geothermal system, confirming the west-to-east flow of the caldera's hydrothermal system. The principal heat source for the system underlies the west moat. 


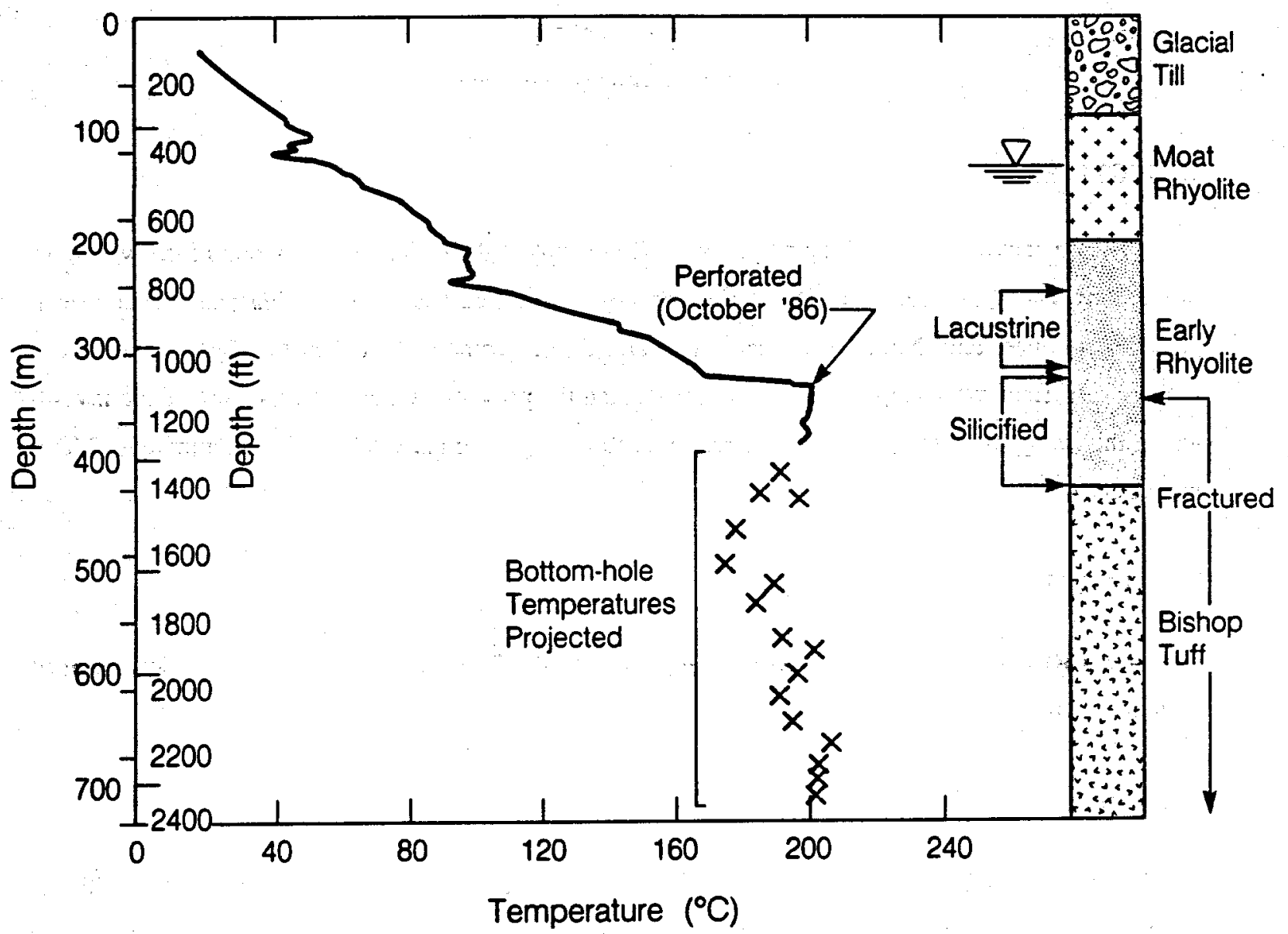

XBL 868-10961

Figure 1. Equilibrium temperature profile, projected temperatures, and lithologic diagram of hole RDO-8. 


\section{DRILLING EXPERIENCE AND PROBLEMS ENCOUNTERED}

RDO-8 was spudded in on May 5 and was completed on June 17, 1986 (45 days). The upper $-90 \mathrm{~m}$ were rotary drilled for surface conductor (PQ), then the hole was cored to T.D. at $\mathrm{H}$ diameter $(9.6 \mathrm{~cm})$. Core recovery exceeded $90 \%$. Difficulties in completing the hole caused by sloughing, squeezing, and lost circulation ruled out attempts to ream in preparation for cementing the $H$ casing. In attempting completion, the hole was initially lost below $245 \mathrm{~m}$, and following a number of attempts to recover it, a "new" hole was cored from 244 to $426 \mathrm{~m}$ and $\mathrm{N}$ casing installed. The hole was then configured for measurement of a thermal gradient and later was perforated at $-335 \mathrm{~m}$ for fluid sampling. At present the hole serves as a site for long-term monitoring of hydraulic pressure of the hydrothermal system.

\section{$\operatorname{cosTS}$}

Drilling: \$184K (DOE: \$112K; Califomia Energy Commission: \$62K; Mono County: \$10K).

Logging: USGS: $\$ 40 \mathrm{~K}$.

Perforation: USGS \$6K.

Scientific activities: DOE support, est. $\$ 150 \mathrm{~K}$ to date, USGS est. $\$ 100 \mathrm{~K}$ to date.

Drilling supervision and logistical support: GRDO: $-\$ 40 \mathrm{~K}$.

\section{RETROSPECTIVE}

The combination of interests to support scientific drilling may often be advantageous. Collaboration with the Califomia Energy Commission and Mono County, whose principal interest was the resource potential for direct use of geothermal fluids, permitted the hole to be cored to $715 \mathrm{~m}$ instead of the originally planned $460 \mathrm{~m}$, based on available DOE support. Most of the scientific objectives of the project would have been achieved, however, at the shallower total depth, and difficulties encountered with completion of the hole might have been avoided or lessened. All in all, though, having nearly $300 \mathrm{~m}$ of fractured, mineralized continuous core of the Bishop Tuff available for scientific examination is a definite plus. In 20/20 retrospect, we should have "planted" the drill string (and bit) as a permanent casing and not have attempted to ream the $\mathrm{N}$-sized portion of the hole to the $\mathrm{H}$ diameter, with the attendant loss of access to the bottom $300 \mathrm{~m}$. However, the regulatory requirement for cementing the final casing over the total depth of the hole necessitated the attempt at reaming. 


\section{FUTURE PLANS}

The heat source of the hydrothermal system, expected to be rock at temperatures exceeding $500^{\circ} \mathrm{C}$ in the sub-caldera basement, should be investigated. In this respect there is a commonality of interest with the Magma Energy program of DOE's Geothermal Technology Division. A phased program is envisioned, encompassing two holes cored into Sierran basement, one on the Rhyolite Plateau north of Mammoth Lakes, another on the north flank of Mammoth Mountain. Information from these holes, together with results of seismic surveys to identify possible magma targets, would be used to site a deep $(-6 \mathrm{~km})$ test hole to the high-temperature rock.

\section{PAPERS DESCRIBING RESULTS OF SHADY REST DRILLING OR INCORPORATING THOSE}

\section{RESULTS}

Flexser, S., and Dayvault, R., Megascopic description of Shady Rest hole core: Lawrence Berkeley Laboratory Report LBL-25601, 1988 (in preparation).

Goff, F., Wollenberg, H., Brookins, D., and Kistler, R., A Sr-isotopic comparison between hydrothermal waters and rocks, Long Valley caldera, California: In preparation, 1988.

Shevenell, L., Goff, F., Grigsby, C.O., Janik, C.J., Truijillo, P.E., Jr., and Counce, D., Chemical and isotopic characteristics of thermal fluids in Long Valley caldera lateral flow systems, Califomia: Transactions, Geothermal Resources Council, v. 10, 1987.

Sorey, M., The hydrothermal system in the west moat of Long Valley caldera: Evidence from recent drill holes and reservoir fluid sampling: In preparation for submittal to J. Geophys. Res., 1988.

Urban, T.C., Diment, W.H., and Sorey, M.L., Hydrothermal regime of the south moat of the Long Valley caldera, Mono County, Califomia, and its relation to seismicity-New evidence from the Shady Rest corehole (RDO-8): Transactions, Geothermal Resources Council, v. 10, 1987.

Urban, T.C., Diment, W.H., and Sorey, M.L., Temperature and natural gamma ray logs for drill hole RDO-8 Mammoth Lakes, Mono County, Califomia: U.S. Geological Survey Open File Report (in preparation), 1987.

Wollenberg, H.A., Sorey, M.L., Farrar, D.D., White, A.F., Flexser, S., and Bartel, L.C., 1987. A core hole in the southwestern moat of Long Valley caldera: Early results: EOS, May 19, 1987, p. 529. 


\section{Appendix 3 \\ Summary of the Valles Caldera Scientific Drilling Program \\ F. Goff \\ Los Alamos National Laboratory}

\section{OBJECTIVES OF PROJECT}

Valles Caldera in the Jemez volcanic field of northern New Mexico is the location of the world "type" resurgent caldera and contains a high-temperature geothermal system $\left(220\right.$ to $\left.300^{\circ} \mathrm{C}\right)$. It also is a young analog of fossil calderas that are mined for precious and base-metal ore deposits. General objectives of the Valles CSDP are (Goff and Nielson, 1986):

1. Study the origin, evolution, and physical/chemical dynamics of the vapor-dominated portions of the geothermal system; map the hot-water-dominated portions of the geothermal system to understand the recharge, heat transfer, convective upflow, and outflow characteristics of the system.

2. Investigate the characteristics of caldera fill and mechanisms of caldera collapse and resurgence.

3. Determine the physical chemical conditions in the heat-transfer zone between crystallized plutons and the hydrothermal system.

4. Study the mechanism of ore deposition within the caldera environment as it relates to the hydrothermal system processes and evolution.

5. Develop and test high-temperature well-drilling techniques and logging tools.

6. Serve as a natural laboratory for the testing and calibration of high-temperature geophysical techniques.

\section{OBJECTIVES OF WELLS DRILLED TO DATE}

\section{VC-1}

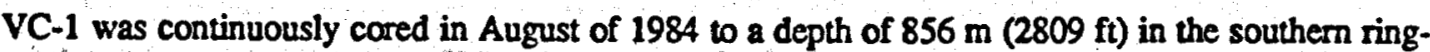
fracture zone of Valles Caldera. Objectives were to (1) intersect the hydrothermal outflow plume of Valles Caldera at a point midway between the source reservoir in the caldera and the terminus at hot springs outside the caldera; (2) investigate the structure, stratigraphy, and hydrothermal alterations in QuatemaryPrecambrian rocks in the ring-fracture zone; and (3) investigate the petrogenesis of the youngest postcaldera volcanic rocks. 
VC-2A

VC-2A was continuously cored in September of 1986 to a depth of $528 \mathrm{~m}(1731 \mathrm{ft})$ at the boundary of the ring-fracture zone and the westem edge of the resurgent dome in Valles Caldera (Fig. 1). Objectives were to (1) study the vapor-dominated zone at Sulphur Springs and the "interface" between the vapor- and liquid-dominated zones; (2) study the stratigraphy and structure of caldera-fill rocks in the resurgent dome; and (3) study ore-deposit mechanisms in an active hydrothermal system.

\section{FINDINGS}

VC-1

1. The section of post-caldera rocks penetrated by VC-1 was unexpectedly thick (335 m). Chemistry and isotopic data show that this sequence of rhyolites $(0.13$ to $-0.4 \mathrm{Ma})$ represents a separate magma batch that has developed since formation of the Bandelier pluton that erupted to form Valles Caldera (1.12 Ma).

2. The Paleozoic and Precambrian rocks penetrated by VC-1 show extensive hydrothermal alteration to phyllic grade. Fluid inclusion work, K/Ar dates on hydrothermal illite, U-Th disequilibrium dates on calcite veins, and paleomagnetic work show evidence of multiple hydrothermal events related to different magmatic episodes in the history of the Jemez volcanic field. The last major episode began at $1.0 \pm 0.1 \mathrm{Ma}\left(\mathrm{T}_{\max }=300^{\circ} \mathrm{C}\right)$ or soon after formation of Valles Caldera.

3. Hydrothermal fluids sampled from VC-1 (present bottom-hole temperature $(B H T)=185^{\circ} \mathrm{C}$ ) are similar in chemical and isotopic composition to deep reservoir fluids in the caldera, proving that the hydrothermal outflow plume exists. Heat flow above the outflow plume is 3 to 4 times greater than conductive heat flow adjacent to the outflow plume outside the caldera. A cross section (Fig. 2) through the southwestem caldera margin shows the configuration of the present Valles hydrothermal system.

\section{VC-2A}

1. The vapor-dominated zone at Sulphur Springs is roughly $250 \mathrm{~m}$ thick and is separated from the liquid-dominated zone by a region of fractured, tightly sealed rock. VC-2A was perforated at $490 \mathrm{~m}$ $\left(210^{\circ} \mathrm{C}\right)$ to sample hydrothermal fluids at the top of the liquid-dominated zone. These fluids are neutral-chloride in character, having substantial amounts of As, B, Br, and Li. Chemical geothermometers indicate equilibration temperatures of 265 to $280^{\circ} \mathrm{C}$ for these fluids.

2. The intracaldera tuffs penetrated by VC-2A show 35 to $45^{\circ}$ of rotation, which is caused by either slumping or resurgence. The entire sequence of rocks is highly faulted and fractured. 


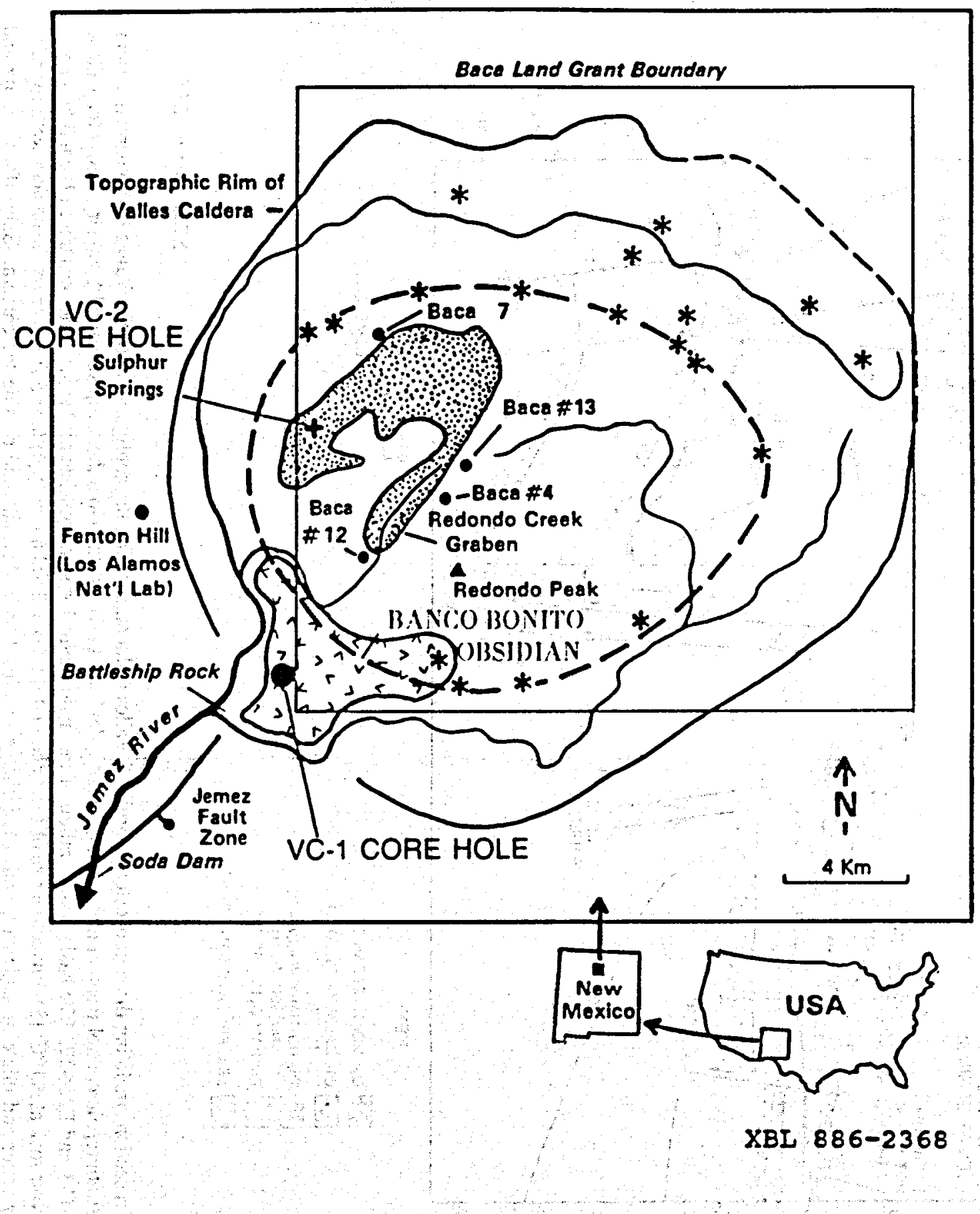

Figure 1. Location map of the Valles Caldera, New Mexico, showing the VC-1 and VC-2A core-hole sites. VC-2B is located at essentially the same spot as VC-2A. Stars denote post-caldera moat rhyolite vents. The Valles ring-fracture zone is marked by the heavy dashed line. The dotted pattern shows the area of most intense surface intra-caldera alterations. The V-pattern shows the youngest post-caldera eruption, the Banco Bonito Obsidian Flow (0.13 Ma). 


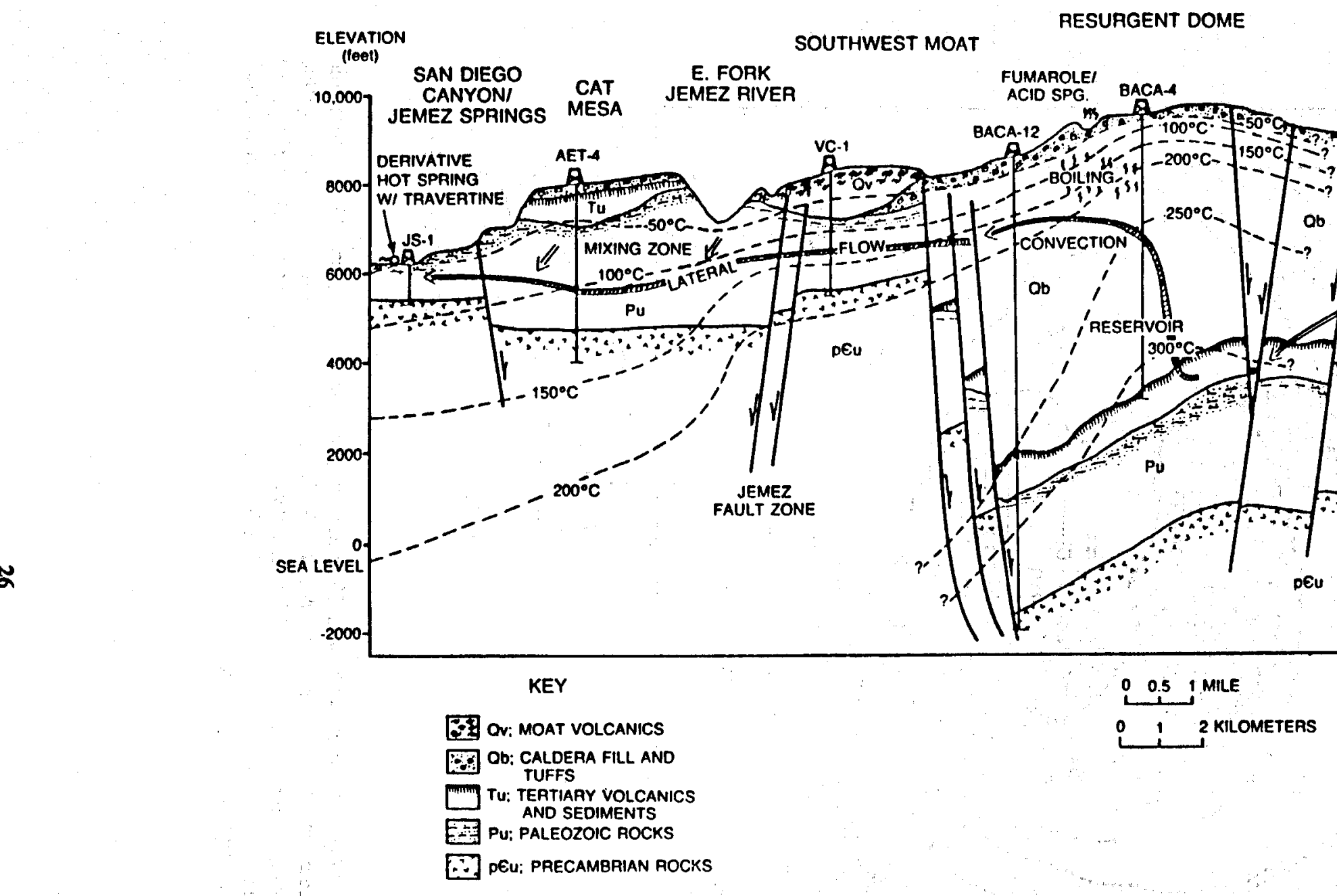

RESUAGENT DOME

XBL $886-2369$

Figure 2. Cross section straddling the southwestem margin of Valles Caldera, showing the configuration of the Valles hydrothermal system. Isotherms and stratigraphic control from surface geology, bore holes, and gravity data. Note the sharp structural boundary across the caldera wall between VC-1 and Baca-12. The basic configuration of the hydrothermal system consists of: (1) meteoric recharge; (2) equilibration of water and reservoir rock at $300^{\circ} \mathrm{C}$; (3) convective rise of hydrothermal fluid (Cl $\left.2500 \mathrm{mg} / \mathrm{kg}\right) ;(4)$ lateral flow across the caldera wall; (5) mix ing of reservoir water and dilute groundwater, and (6) discharge of mixed hydrothermal fluid outside the caldera. Subsurface boiling and release of volatiles creates acid springs and fumaroles above the zone of convection. Dating of travertine deposits at mixed (or derivative) hot-spring areas outside the caldera shows this system has been active for approximately $1 \mathrm{~m} . \mathrm{y}$. 
3. All rocks penetrated by VC-2A display moderate to intense hydrothermal alteration. A sub-oregrade molybdenum deposit was penetrated from 25 to $125 \mathrm{~m}$ ( $\leq 0.6 \mathrm{wt} \% \mathrm{MoS}_{2}$ ). The mineral assemblage in this zone is pyrite, quartz, illite, fluorite, molybdenite, chalcopyrite, and thodocrosite. Fluid-inclusion studies show that the ore was deposited at 200 to $225^{\circ} \mathrm{C}$ from liquid water. Because this zone is now vapor-dominated, the liquid-dominated portion of the hydrothermal system has descended since the ore-forming event ( $\leq 1 \mathrm{Ma})$.

\section{LONG-TERM SCIENTIFIC RETURNS}

The anticipated long-term scientific returns of the Valles CSDP are better knowledge of the magmatic, structural, hydrothermal, and ore-forming processes and evolution of these processes in a large silicic caldera. These processes will lead to improved understanding of geothermal energy development, precious and base-metal ore deposits, and volcanic hazards.

\section{DRILLING PROCEDURES}

VC-1 (Depth, $\left.856 \mathrm{~m} ; \mathrm{BHT}, 185^{\circ} \mathrm{C}\right)$

VC-1 was cored using a standard mining industry diamond-core rig modified with blowout preventer. No unusual problems other than "sticky" drill rods in clay-rich zones in Paleozoic rocks were encountered. Core recovery exceeded 95\%. A full suite of standard geophysical logs was obtained immediately after drilling. Temperature logs were obtained periodically through the summer of 1987 . The hole was lined from top to bottom after drilling, and two zones were perforated to obtain fluid samples. VC-1 is still accessible for experiments.

VC-2A (Depth, $528 \mathrm{~m} ; \mathrm{BHT}, 212^{\circ} \mathrm{C}$ )

VC-2A was cored in a very hostile environment at Sulphur Springs, where surface thermal features reach $95^{\circ} \mathrm{C}$ and surface $\mathrm{pH}$ car be as low as 0.5. A standard diamond-core rig was used; however, a large blowout preventer was needed. In addition, three heavy casings with acid-resistant cement were set to a depth of $98 \mathrm{~m}$. An elaborate $\mathrm{H}_{2} \mathrm{~S}$ monitoring system was emplaced for health and safety reasons. No drilling problems were encountered. Core recovery exceeded $98 \%$. Because of the high temperature and small diameter of the well (3 in. I.D.) and fear of hole collapse, the drilling rods were planted as a liner, and only neutron and gamma logs were obtained besides temperature logs. During 1987, several additional temperature logs and STP logs were obtained. The well was perforated at $490 \mathrm{~m}\left(210^{\circ} \mathrm{C}\right)$, and many flow tests and some in-situ sampling runs have been conducted. VC-2A is still accessible for experiments, but it flows superheated geothermal fluids when opened. A major problem has been finding high-temperature 
equipment that will perform in a hot slim hole.

\section{costs}

VC-1

VC-1A cost $\$ 240,000$ to drill $(\$ 280 / \mathrm{m})$. About $\$ 200,000$ was provided by DOE/OBES, while $\$ 40,000$ came from other sources. Science activities in VC-1 are valued at $\$ 1,470,000$ from October 1984 to September 1987 , of which $\$ 410,000$ was provided by DOE/OBES.

\section{VC-2A}

VC-2A cost $\$ 190,000$ to drill $(\$ 360 / \mathrm{m})$, and all funds were provided by DOE/OBES. Science activities in VC-2A are valued at $\$ 725,000$ from October 1986 to September 1987 , of which $\$ 325,000$ was provided by DOE/OBES.

\section{RETROSPECTIVE LOOK}

As the Valles CSDP has evolved, we started with a modest interlaboratory effort that cored VC-1 and developed a broad-based drilling plan and scientific constituency that produced VC-2A and intends to core at least one more scientific well (VC-2B). In retrospect, I would do nothing different; all objectives were obtainable, all objectives were met, several discoveries were made, many national and international researchers got involved in the science, and much more was leamed than was ever expected. All this was accomplished with very modest drilling costs in some extremely hostile drilling conditions, using small innovations in diamond-coring techniques. Much more will come out of the core and fluid samples obtained. As for me (Fraser Goff), I am stepping down from the lead PI role to pursue the science (I need the break).

For the future, I envision drilling deeper and hotter $\left(5.5 \mathrm{~km}\right.$ and $\left.500^{\circ} \mathrm{C}\right)$ to study the roots of the hydrothermal system and its connection to the crystallizing magma beneath the caldera; "wo go where no man has gone before." Drilling Katmai, Yellowstone, and Mt. St. Helens seems like a great possibility.

\section{SELECTED PUBLICATIONS RESULTING FROM VC-1 AND VC-2A}

VC-1

1. Goff, F., J. Rowley, J. N. Gardner, W. Hawkins, S. Goff, R. Charles, D. Wachs, L. Maassen, and G. Heiken, Initial results from VC-1, first Continental Scientific Drilling Program Core Hole in Valles caldera, New Mexico: J. Geophys. Res. 91, 1742-1752, 1986.

2. Goff, F., and D. L. Nielson (eds.), Caldera processes and magmahydrothermal systems; Continental 
Scientific Drilling Program-Thermal Regimes, Valles caldera research, scientific and management plan: Los Alamos National Laboratory report LA-10737-OBES, 163 pp., 1986.

3. Rowley, J., W. Hawkins, and J. Gardner, Drilling report, first CSDP/Thermal Regimes core hole project at Valles caldera, New Mexico (VC-1): Los Alamos National Laboratory Report LA-10934-OBES, 61 pp. 1987.

4. Gardner, J. N., F. Goff, S. Goff, et al., Core lithology, Valles caldera \#1, New Mexico: Los Alamos National Laboratory Report LA-10957-OBES, 273 pp., 1987.

5. Manley, C. R., and J. H. Fink, Intemal textures of rhyolite flows as revealed by research drilling: Geology 15, 549-552, 1987.

6. Dey, T. N., and R. L. Krantz, State of stress and relationship of mechanical properties to hydrothermal alteration at Valles caldera, Corehole \#1, New Mexico: J. Geophys. Res. (in press).

7. Geissman, J. W., Paleomagnetism and rock magnetism of Quaternary volcanic rocks and late Paleozoic strata, VC-1 corehole, Valles caldera, New Mexico, with emphasis on remagnetization of late Paleozoic strata: J. Geophys. Res. (in press).

8. Goff, F., L. Shevenell, J. N. Gardner, F.-D. Vuataz, and C. O. Grigsby, The hydrothermal outflow plume of Valles caldera, New Mexico and a comparison with other outflow plumes: J. Geophys. Res. (in press).

9. Hulen, J. B., and D. L. Nielson, Hydrothermal brecciation in the Jemez fault zone, Valles calderaResults from CSDP corehole VC-1: J. Geophys. Res. (in press).

10. Higgins, M. D., Light lithophile element $(B, L i)$ abundances in the Valles caldera, New Mexico, VC-1 corehole: J. Geophys. Res. (in press).

11. Keith, T. E. C., Alteration in the Madera Limestone and Sandia Formation from corehole VC-1, Valles caldera, New Mexico: J. Geophys. Res. (in press).

12. Sasada, M., Microthermometry of fluid inclusions from the VC-1 corehole in Valles caldera, New Mexico: J. Geophys. Res. (in press).

13. Sass, J. H., and P. Morgan, Conductive heat flux in VC-1 and the thermal regime of the Valles caldera, Jemez Mountains, New Mexico: J. Geophys. Res. (in press).

14. Sturchio, N. C., and C. M. Binz, Uranium-series age determination of calcite veins, VC-1 drill core, Valles caldera, New Mexico: J. Geophys. Res. (in press).

15. Vuataz, F.-D, F. Goff, C. Fouillac, and J.-Y. Calvez, A strontium isotope study of the VC-1 corehole and associated hydrothermal fluids and rocks from Valles caldera, Jemez Mountains, New Mexico: J. Geophys. Res. (in press).

VC-2A

1. Goff, F., D. L. Nielson, J. N. Gardner, J. B. Hulen, P. Lysne, L. Shevenell, and J. C. Rowley, Scientific drilling at Sulphur Springs, Valles caldera, New Mexico: Corehole VC-2A: EOS 68, 649-662, 1987.

2. Hulen, J., D. Neilson, F. Goff, J. N. Gardner, and R. Charles, Molybdenum mineralization in an active geothermal system, Valles caldera, New Mexico: Geology 15, 748-752, 1987.

3. Starquist, V. L., Core log Valles caldera \#2A, New Mexico: Los Alamos National Laboratory Report LA-11176-OBES, 87 pp., 1988.

\section{AGENCIES CONTRIBUTING TO RESEARCH}
A. Los Alamos National Laboratory
B. Sandia National Laboratories
C. Lawrence Berkeley Laboratory
D. Argonne National Laboratory
E. Oak Ridge National Laboratory
F. University of Utah Research Institute
G. U.S. Geological Survey
H. Arizona State University
I. Northern Arizona University
J. University of Califomia, Berkeley 
K. University of California, Riverside

L. Massachusetts Institute of Technology

M. Georgia Tech

N. New Mexico Institute of Mining and Technology

O. University of New Mexico

P. University of Nevada, Reno

Q. State University of New York, Albany
R. University of Texas, Arlington

S. Terra Tek Research, Salt Lake City

T. University of Toronto (Canada)

U. McMaster University (Canada)

V. BRGM (France)

W. Israeli Geological Survey

X. Japanese Geological Survey

Y. Yamaguchi University (Japan) 


\title{
Appendix 4
}

\section{Summary of Salton Sea Shallow Drilling Program}

\author{
L. Younker
}

Lawrence Livermore National Laboratory

\section{GOALS OF STUDY}

The Salton Trough is a sediment-filled rift zone where "leaky" transform faults provide paths for magma to intrude into the crust. The Salton Sea Geothermal Field (SSGF) is one site where young intrusions provide heat and materials to transform sediments into new continental crist. A simple conceptual model had been used to understand the magma-hydrothermal system, but several important constraints were unknown. Previous drilling in the SSGF had detected a conductive thermal cap, indicating that $80-\mathrm{m}$ temperature-gradient holes could be used to study the thermal anomaly. Only part of the anomaly had been drilled, and none of the high heat-flow contours were closed. The objectives of the drilling program were:

(1) to constrain the shape and lateral extent of the thermal anomaly by completing the surficial coverage offshore in the region north of the line of exposed volcanos thought to represent its center;

(2) to incorporate these new observations into conceptual models of the evolution of the magmahydrothermal system; and

(3) to use those models to understand the role of this local "hot-spot" in the crustal rifting process.

\section{SHORT-TERM FINDINGS}

The shape of the region of high thermal gradients is offset to the south of the line of volcanos previously thought to represent the center of the field. The thermal anomaly has an arcuate shape, about $4 \mathrm{~km}$ wide and $12 \mathrm{~km}$ long. The transition zone between locations exhibiting high thermal gradients and those exhibiting regional thermal gradients is quite narrow: thermal gradients rise from near regional $\left(0.09^{\circ} \mathrm{C} / \mathrm{m}\right)$ to extreme $\left(0.85^{\circ} \mathrm{C} / \mathrm{m}\right)$ in only $2.4 \mathrm{~km}$. The heat flow in the central part of the anomaly is $>600 \mathrm{~mW} / \mathrm{m}^{2}$, and two areas with twice that heat flow were discovered.

\section{ANTICIPATED FOLLOW-UP SCIENTIFIC RETURNS}

The complete thermal survey has changed our view of the geothermal system, which is now seen to have several scales of circulation. These observations, and thermal and chemical data along a vertical profile in the SSSDP hole, will be put into models being developed by several groups. The output of these models will allow us to better understand the evolution and present state of the system and to provide con- 
straints on regional mechanisms of crustal rifting. Two additional studies have been completed with funding from the UC-IGPP. Dr. Lee of UC-Riverside has studied the thermal-conductivity distribution in the cuttings and core recovered, and Prof. Kastner and Ann Sturz of Scripps have examined near-surface alteration that occurs near one of the newly discovered "hot spots."

\section{DRILLING PROCEDURES USED}

We drilled $1980-\mathrm{m}$ holes offshore in the region north and west of the volcanic domes. The drilling sites were located using a Motorola Miniranger ${ }^{\mathrm{m} s}$ system, and each site was buoyed for ready identification. The holes were drilled with a truck-mounted rig set on a floating barge with retractable legs, using sea water for circulation. The holes were cased with one-inch-diameter PVC pipe, filled with sea water, and sealed at the bottom against infiltration of the formation or surface fluids. The casing was cemented in place through a stinger. The conductor stripped over the PVC, which stood above the sea level. The PVC was secured to a pipe driven into the lake bottom and buoyed to minimize navigational hazards during several months while temperatures were recorded. Ultimately, the PVC was filled with cement and capped at the sea floor. The temperature data were combined with results released as part of the Salton Sea Scientific Drilling Program by Kennecott-Bear Creek Mining in order to complete coverage of the field.

\section{Problems Encountered}

Weather was our main problem. We lost the opportunity to drill several holes because of damage to the drilling barge in two separate storms. Some holes were lost before logging was completed, due to a combination of adverse weather, the weight of rapid barnacle growth, and vandalism. The most important hole was lost before any temperature logs were acquired in it. The expense of searching for these holes added to the abandonment costs. Lost circulation was common, and it resulted in some holes being shorter than planned.

\section{COST: DRILLING AND SCIENCE}

Drilling: $\$ 298.6 \mathrm{~K}$

Science: $\$ 248 \mathrm{~K}$

\section{RETROSPECTIVE: LESSONS WE HAVE LEARNED}

First, the scientific frontier in crustal thermal regimes can be relatively shallow in depth. With regard to hydrothermal systems, it is clear that shallow fluid transport substantially affects the nature of crustal thermal anomalies. Understanding this flow regime is essential for drawing inferences about the 
deeper heat sources, and their location and character. Shallow drilling at the Salton Sea has helped to constrain these flow pathways and significantly changed our view of the nature of that system. Second, in this initial state of thermal-regimes drilling, multiple holes are probably essential in order to remove fundamental ambiguities and put the drilling results into context. Temperature will always be a prime observation in any thermal-regimes drilling program, and yet isolated observations provided by single boreholes are likely to be uninterpretable due to the possibility of complex flow patterns. This experiment and the SSSDP 12,000-foot hole complemented each other, illustrating that a combination of depth and areal coverage provides the best opportunity for understanding systems in the Earth. Third, we believe that this project was a success in part because the drilling program was based on a testable hypothesis, based on extensive site investigations, that made specific predictions for the targeted region. Fourth, after we lost several days of drilling, we felt that extending the project by two more days would have been very worthwhile. Unfortunately, our contract and funding were not flexible enough to do it. Naturally, most projects end with the desire to do a little more, and a means must be set up to decide when to end projects based on scientific payoff. Finally, next time we would make a better guess about the weather!

\section{PUBLICATIONS RESULTING FROM THE SALTON SEA SHALLOW THERMAL GRADIENT PROJECT}

Full Reports

Newmark, R.L., P.W. Kasameyer, L.W. Younker, and P.C. Lysne, Research drilling at the Salton Sea geothermal field, Califomia: The shallow thermal gradient project: EOS, Transactions Am. Geophys. Union, 167, No. 39, 698-707, 1986.

Kasameyer, P.W., and L.W. Younker, Geothermal programs at Lawrence Livermore National Laboratory: Geothermal Resources Council Transactions, 11; Lawrence Livermore National Laboratory Report UCRL-97181, 1987.

Younker, L.W., J.C. Eichelberger, P.W. Kasameyer, RL. Newmark, and T.A. Vogel, Results from shallow research drilling at Inyo Domes, Long Valley Caldera, California, and Salton Sea geothermal field, Salton Trough, California, Proceedings of the Third International Symposium on Observation of the Continental Crust through Drilling, Moira, Sweden: Lawrence Livermore National Laboratory Report UCRL-97583, 1987.

\section{Abstracts Presented}

Kasameyer, P.W., and L.W. Younker, The Salton Sea geothermal field: A target for continental scientific drilling, Southwestern and Rocky Mountain Division, AAAS, 61st Annual Meeting, Tucson, AZ: Lawrence Livermore National Laboratory Report UCRL-91992, 1985.

Newmark, R.L., and P.W. Kasameyer, Thermal sources for the Salton Sea geothermal field: Results for thermal modeling: Spring Amer. Geophys. Union Meeting, Baltimore, MD, 1988.

Newmark, R.L., P.W. Kasameyer, and L.W. Younker, Thermal gradients in the southern Salton Sea region: Spring Amer. Geophys. Union Meeting, Baltimore, MD, 1985.

Newmark, R.L., P.W. Kasameyer, and L.W. Younker, Thermal gradients in the Salton Sea region: the shallow thermal gradient project: Spring Amer. Geophys. Union Meeting, Baltimore, MD 1986. 
Kasameyer, P.W., L.W. Younker, R.L. Newmark, and A.G. Duba, Drilling investigations of crustal rifting processes in the Salton Trough, Califomia, DOSECC Workshop, Rapid City, SD: Lawrence Livermore National Laboratory Report UCRL-94566, Rev. 1, June 1986.

Newmark, RI., P.W. Kasameyer, and L.W. Younker, Scientific drilling, heat flow and the crustal rifting process in the Salton Trough: Spring Amer. Geophys. Union Meeting, Baltimore, MD, 1987.

Newmark, R.L., Scientific drilling, heat flow and the crustal rifting process in the Salton Trough: Industrial Associates Symposium in Scientific Well Logging, Lament-Doherty Geological Observatory, New York, March 1987.

Yi, Z., and T.C. Lee, On the shallow hydrothermal regime of the Salton Sea geothermal field, California: Fall Amer. Geophys. Union Meeting, San Francisco, CA, 1987.

Manuscripts in Preparation

Newmark, R.L., P.W. Kasameyer, and L.W. Younker, Shallow drilling in the Salton Sea region: The thermal anomaly: Under revision for J. Geophys. Res.; Lawrence Livermore National Laboratory, UCRL-97501, Rev. A.

Newmark, R.L., P.W. Kasameyer, and L.W. Younker, Preliminary report on shallow drilling in the Salton Sea region: Lawrence Livermore National Laboratory.

Sturz, A., Low temperature hydrothermal alteration in near surface sediments, Salton Sea Geothermal area: Submitted to J. Geophys. Res. 


\title{
Appendix 5
}

\section{The Salton Sea Scientific Drilling Project}

\author{
W. Elders \\ University of California, Riverside \\ and \\ J. Sass \\ United States Geological Survey, Flagstaff, Arizona
}

\section{ABSTRACT}

In March 1986 a research borehole, called the "State 2-14," reached a Depth of $3.22 \mathrm{~km}$ in the Salton Sea geothermal system of southern Califomia. This was part of the Salton Sea Scientific Drilling Project (SSSDP), the first major (i.e, multimillion dollar) research drilling project in the U.S. Continental Scientific Drilling Program. The principal goals of the project were to investigate the physical and chemical processes of a high-temperature, high-salinity, magmatically driven hydrothermal system. The borehole encountered temperatures of up to $355^{\circ} \mathrm{C}$ and produced metal-rich, alkali chloride brines containing 25 weight \% of total dissolved solids. The rocks penetrated exhibit metamorphism and ore genesis in action. They show a progressive transition from unconsolidated lacustrine and deltaic sediments to homfelses, with lower amphibolite facies mineralogy, accompanied by pervasive veins containing iron, copper, lead, and zinc ore minerals. The SSSDP included an intensive program of rock and fluid sampling, flow testing, and downhole logging and scientific measurement. The purpose of this paper is to introduce this special issue of the Journal of Geophysical Research on the SSSDP, to describe briefly the background of the project and the drilling and testing of the bosehole, to summarize the initial scientific results, and to discuss how the lessons learned are applicable to future scientific drilling projects.

\section{INTRODUCTION}

The Salton Sea Scientific Drilling Project (SSSDP) was bom in frustration, a frustration common to most proponents of scientific drilling. Although the results of past geological processes are available for study at outcrops, drilling is the best practical method of studying the active processes shaping the outer few kilometers of the Earth's crust. Hydrothermal processes occur largely in this domain. Scientists studying hydrothermal phenomena can only measure the temperatures and sample the fluids and rocks in place by drilling into hot zones. However, drilling is frustratingly expensive. The frustration of scientists is To be published in the Journal of Geophysical Research. 
compounded by the fact that, although many geothermal wells are drilled by industry, in this country at least, many of the data and samples produced are kept proprietary.

Meanwhile, in the U.S.A. the concept of drilling the continents for scientific purposes has been debated for decades (e.g., Shoemaker, 1974). However, it was not until 1984, with the adoption of the "Interagency Accord on Continental Scientific Drilling" by the National Science Foundation (NSF), United States Geological Survey (USGS), and Department of Energy (DOE), that much progress was made towards implementing a national program (Stehli and Andrews, 1987). Frustration with this lengthy gestation, and with the difficulty of obtaining samples and data from geothermal systems, stimulated W.A. Elders, in the Fall of 1982, to make a proposal to the National Academy of Sciences to drill a series of research boreholes in the Salton Sea geothermal system (SSGS) of California, one of the largest and hottest geothermal fields in the world (Fig. 1). However, there seemed to be no practical way to implement the plan. Discussions with the NSF, USGS, and DOE made it clear that these agencies did not have sufficient funding for this proposal, even though it was receiving widespread support from fellow scientists. Consequently Elders took the funding request for the Salton Sea Scientific Drilling Project directly to the U.S. Congress, which responded by adding $\$ 5.9$ million for Phase 1 of the SSSDP to the 1984 budget of the Geothermal Technology Division of DOE. The history of these negotiations, and the subsequent organization that developed, has been described elsewhere (Elders, 1985). In May 1984, DOE selected a major engineering company, Bechtel National, Inc., to drill on a site offered by Kennecott, Inc., a resource company holding leases in the SSGS. The borehole was successfully drilled between October 1985 and March 1986. Eventually the budget for the drilling, engineering, and management of the SSSDP grew to be \$6.7 million. A further $\$ 2.65$ million of scientific studies was funded jointly by the USGS, NSF, and DOE (Adduci et al., 1986). In all, some 40 different science and technology development projects were involved (Sass and Elders, 1986).

Our aims in the SSSDP were to probe the roots of a very hot geothermal system, a unique hypersaline environment never before thoroughly investigated scientifically. By drilling and testing a deep and very hot research borehole, we also expected to advance the basic science and technology underlying development of geothermal resources. Highlights of Phase 1 of the SSSDP included:

- a depth of $3,220 \mathrm{~m}$ and temperatures of $355 \pm 10^{\circ} \mathrm{C}$ were reached;

- the commercial potential of deeper geothermal resources in the SSGS, with high flow rates measured at $\leq 350$ tonnes/hr, was proved;

- $224 \mathrm{~m}$ of rock core were obtained, demonstrating transitions from unconsolidated lake sediments to highly metamorphosed rocks of lower amphibolite facies, with locally abundant ore minerals; 


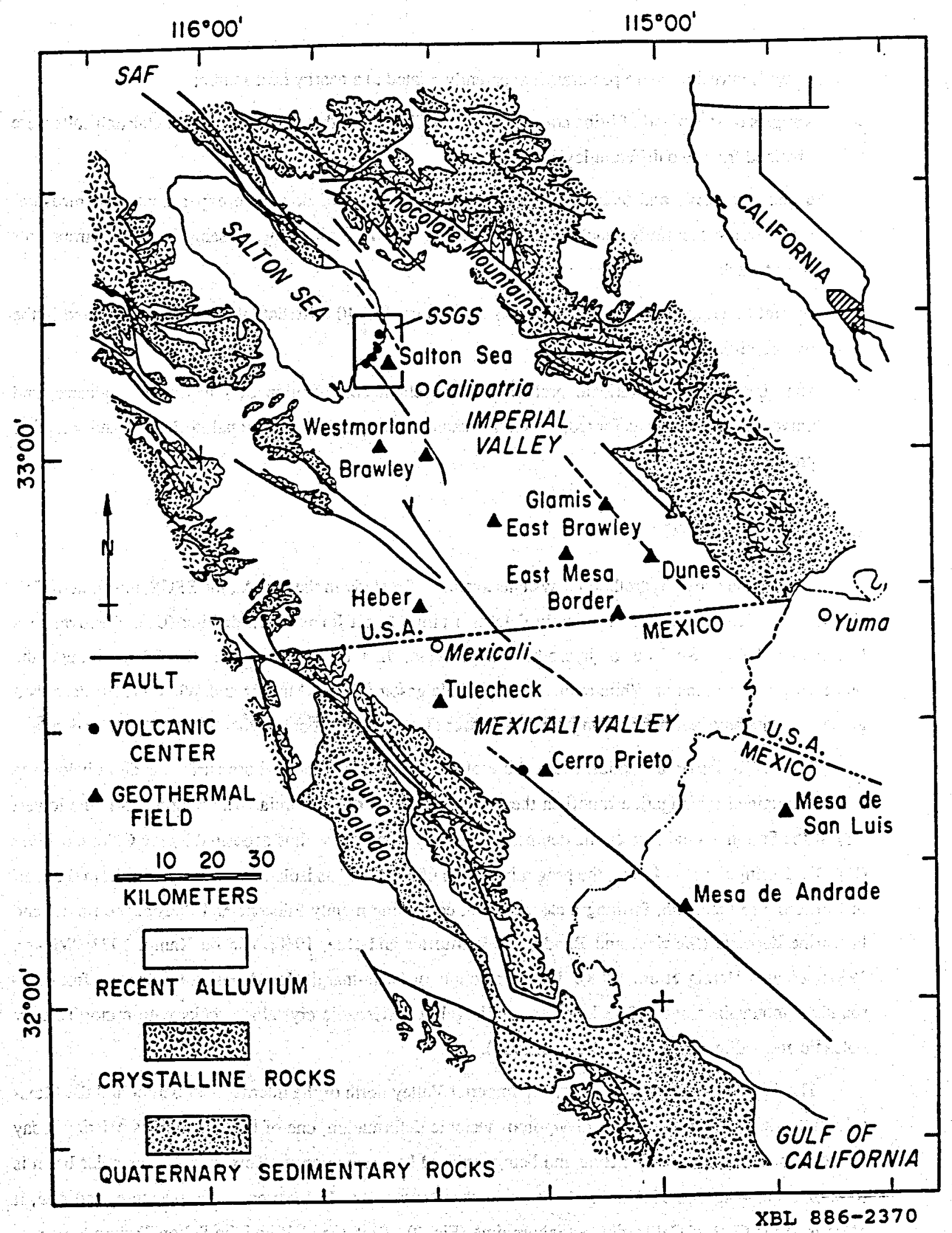

Figure 1. Geology of the Salton Trough and the location of its geothemal fields. The Salton Sea Geothermal System (SSGS) is the largest and most saline high-temperature hydrothermal system in the Trough. The rectangle marked "SSGS" shows the location of the maps shown in Figs. 3 and 4. The dotted line marks the approximate position of the apex of the delta. 
- igneous intrusions were penetrated, apparently related to a nearby heat source;

- samples of steam and of brine containing > 25\% TDS (total dissolved solids) of metal-rich salts were obtained from two different levels;

- a comprehensive and technologically sophisticated series of downhole experiments and measurements was successfully concluded, and advanced systems for logging and sampling hot environments were tested;

- several hundred scientists and engineers from more than $\mathbf{4 0}$ different laboratories participated in the overall project;

- after initial inter-institutional problems, an excellent collaboration of government, industry, and university agencies was forged, which overcame challenging organizational, technical, and scientific problems.

\section{GEOLOGIC SETTING}

Among the active hydrothermal systems available for study in the U.S.A., the SSGS, in southern Califomia (Fig. 1), was selected at an early date as a prime target for research drilling (U.S. Geodynamics Committee, 1979). Students of hydrothermal processes first became aware of the SSGS through the pioneering publications of White et al. (1963) and Helgeson (1968). Muffler and White (1969) described greenschist metamorphism occurring at temperatures above $300^{\circ} \mathrm{C}$, at only two to three kilometers depth.

The SSGS lies on the southeastern shore of the Salton Sea, a lake whose surface is $68 \mathrm{~m}$ below sea level, maintained by irrigation runoff in the arid lower desert of Califomia. The Salton Sea is the lowest part of the Salton Trough, a tectonic depression partially filled by detritus deposited by the Colorado River (Fig. 1). During the past 4 m.y., the prograding delta of the river has isolated this depression from the Gulf of California to the south, forming a closed basin, containing mainly Pliocene and Pleistocene fluvial and lacustrine deposits (Merriam and Bandy, 1965; Muffler and Doe, 1968; Van de Kamp, 1973; Winker, 1987; see also Herzig et al., 1988). Lesser amounts of basin-margin fan deposits are derived from surrounding mountain ranges. The latter consist largely of Mesozoic crystalline rocks with minor Tertiary volcanic and sedimentary rocks (Dibblee, 1954).

The Salton Trough, consisting of the Imperial Valley north of the international border and the Mexicali Valley south of it, is an area of vigorous tectonic deformation, one of the few regions existing today where a continent is actively rifting and being replaced by oceanic crust. This roughly triangular basin is some $350 \mathrm{~km}$ long and $120 \mathrm{~km}$ wide at its southern extremity. In location, gross structure, and size, it belongs to the Gulf of Califomia tectonic regime (Fig. 2). Both the Gulf and the Salton Trough have patterns of rapid geodetic deformation, high heat flow, frequent seismicity, and volcanism that reflect the transition from the divergent tectonics of the East Pacific Rise, to the south, to the transform tectonics of the 


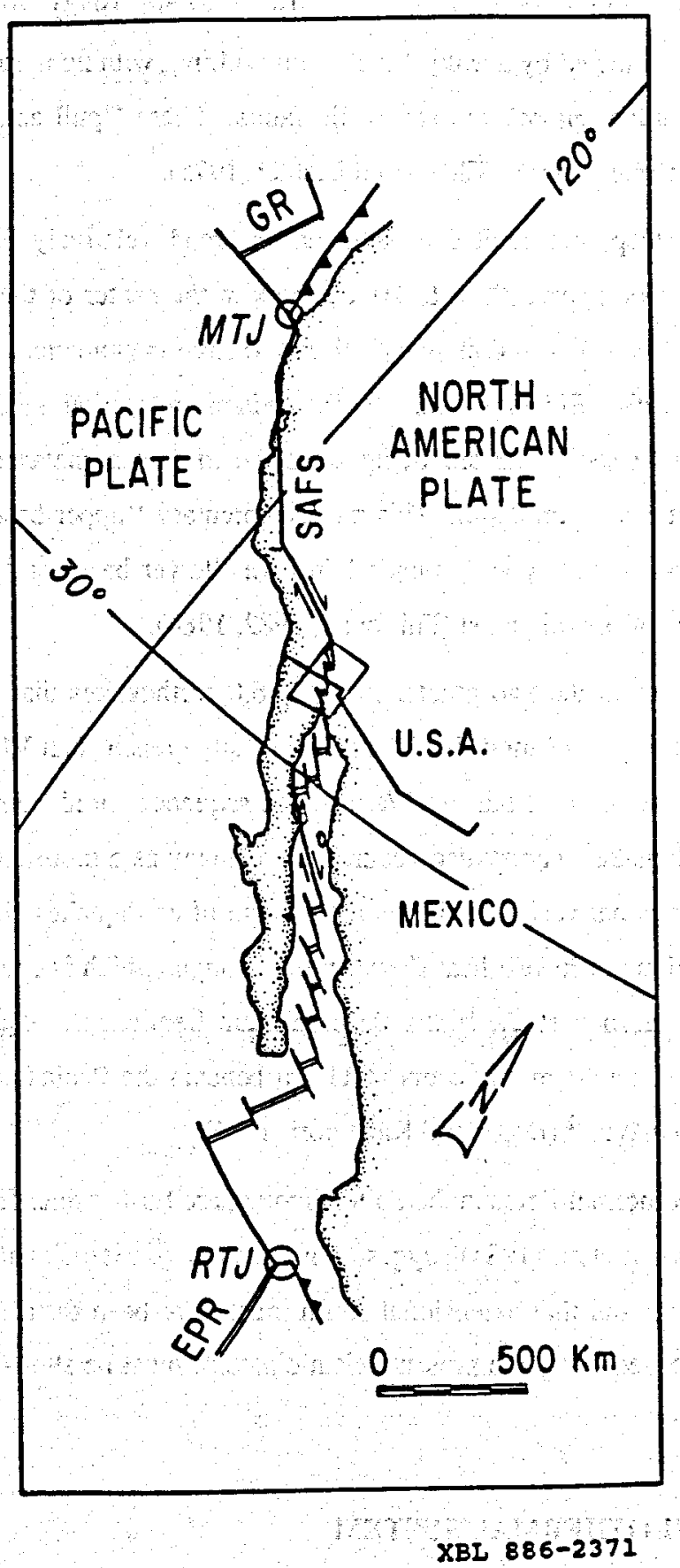

Figure 2. The boundary between the Pacific and North American plates. The rectangle shows the location of the Salton Trough at the head of the Gulf of Califomia, a tectonic regime transitional between the East Pacific Rise (EPR) and the San Andreas Fault System (SAFS). Other abbreviations are GR-Gorda Rise; MTJ-Mendocino Triple Junction; RTJ-Rivera Triple Junction (modified after Lachenbruch et al., 1985, Fig. 1). 
San Andreas Fault system, to the north (Elders et al., 1972; Moore, 1973). Both the Salton Trough and the Gulf of California are dominated by "leaky" transform faulting, with numerous tensional zones developed at the ends of right-stepping, en echelon strike-slip faults. These "pull apart" structures are the loci of high-temperature geothermal systems (Elders and Biehler, 1975).

The Trough has steep, step-faulted margins and a broad, relatively flat basement floor, beneath a cover of sedimentary rocks, apparently 6 to $10 \mathrm{~km}$ thick in the center of the Imperial Valley (Fuis et al., 1982, 1984). In spite of the thick sedimentary fill, the Trough is characterized by a positive gravity anomaly (Biehler et al., 1964; Elders et al., 1972). Seismic-refraction studies are consistent with the hypothesis that the young sediments are being transformed into a metasedimentary basement by high ambient temperatures at 5 to $6 \mathrm{~km}$ depth. This metasedimentary "upper basement" persists to a depth of 10 to $16 \mathrm{~km}$ in the Imperial Valley and is underlain by a "lower basement" with seismic properties and densities similar to those of oceanic crust (Fuis et al., 1982, 1984).

This century, including the two greater than $M_{L} 6.0$ earthquakes that occurred in November 1987 , there have been 14 earthquakes of modified Mercalli intensity greater than VIII in the Salton Trough. Two distinct types of seismicity occur. Mainshock/aftershock sequences produce mainly right-lateral strike-slip faulting. Frequent earthquake swarms also occur, with as many as a thousand events in a few days (Johnson and Hill, 1982). Regional variations in the focal depth of earthquakes $\propto c c u r$, with the deepest seismicity associated with regions of lowest heat flow. In the Trough, which is characterized by high heat flows of $>100 \mathrm{mWm}^{-2}$ (Lachenbruch et al., 1985), the maximum frequency of depths of hypocenters occurs at only $7 \mathrm{~km}$. In contrast, the maximum occurs at $11 \mathrm{~km}$ beneath the Peninsular Ranges to the west, where heat flows average $<80 \mathrm{mWm}^{-2}$ (Doser and Kanamori, 1986).

The numerous geothermal fields in the Salton Trough are further manifestations of the high heat flow of the region. Lachenbruch et al. (1985) suggest that the average extensional strain rate in the Trough has been about $20-50 \% / \mathrm{m} . y$. and that extensional strain must have been distributed over a spreading region about $150 \mathrm{~km}$ wide. Consequently the present seismic pattern must be short-lived on the time scale of the formation of the Trough.

\section{THE SALTON SEA GEOTHERMAL SYSTEM}

The SSGS itself has heat flow in excess of $200 \mathrm{mWm}^{-2}$ (Lachenbruch et al, 1985; see also Fig. 9 of Sass et al., 1988). In addition, it exhibits a residual Bouguer gravity anomaly of +23 milligals (Biehler, 1974), presumably due to both the densification of the sediments and the presence of igneous intrusions (Fig. 3A). A positive magnetic anomaly of $10^{-6}$ tesla, 5 to $8 \mathrm{~km}$ wide, extends $28 \mathrm{~km}$ northwesterly from Calipatria over the southern part of the Salton Sea (see Fig. 3B). Griscom and Muffler (1971) suggest that this is due to the presence of mafic dike swarms at depths greater than $2.25 \mathrm{~km}$. In addition, several small 


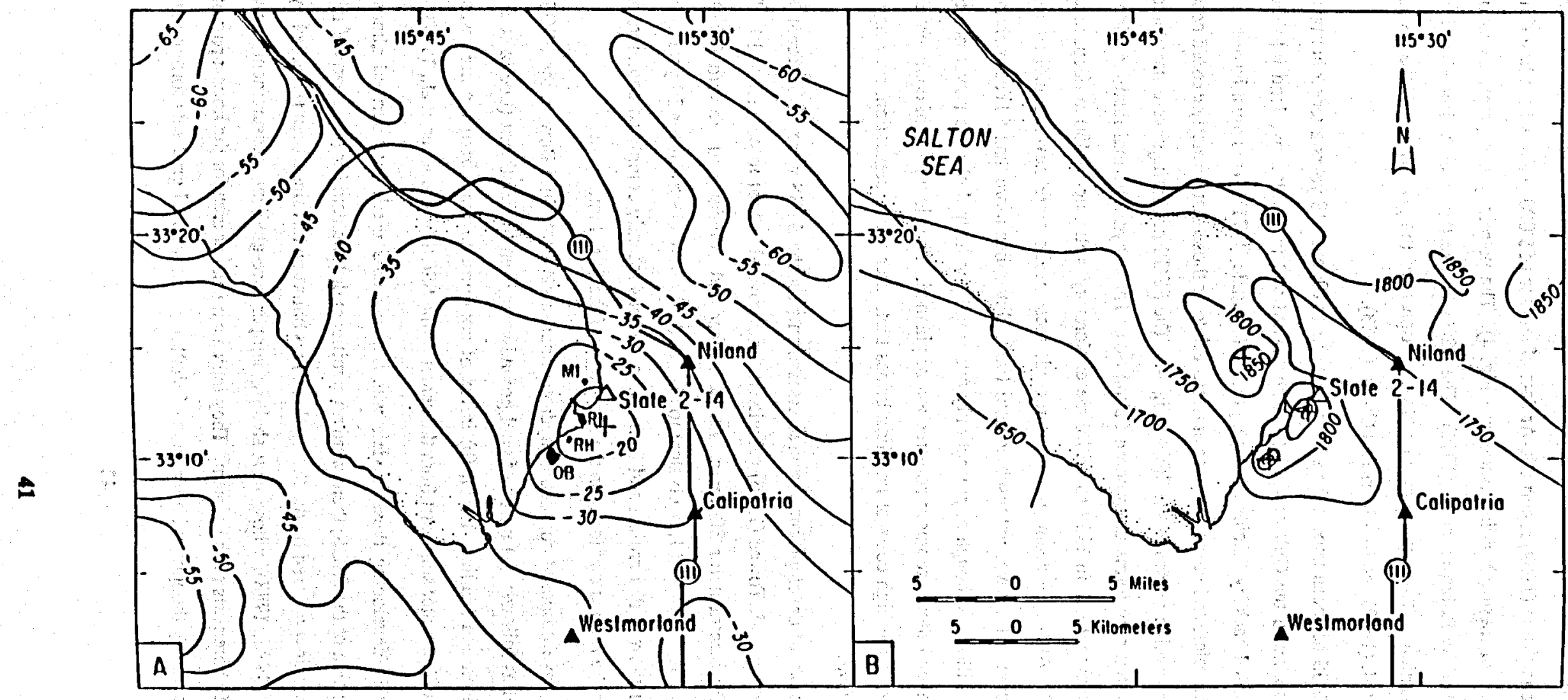

XBL $886-2372$

Figure 3. Geophysical anomalies in the area surrounding the State 2-14 borchole and the Salton Sea geothermal field. The Quaternary volcanoes, OB-Obsidian Butte, RH-Rock Hill, RI-Red Island (two domes), and MI-Mullet Island, are also shown. (A). Bouguer gravity map; the contour interval is $5 \mathrm{mgal}$. The plus sign marks the center of a +23 -mgal residual anomaly (modified from Biehler, 1974). (B). Aeromagnetic map of total-intensity magnetic ficld, the contour interval is 50 nannoteslas ( 50 gammas). The plus signs show locations of local positive magnetic anomalies of $1 \times 10^{-8}$ to $1 \times 10^{-7}$ teslas, some of which coincide with the Quatemary rhyolite domes (modified after Griscom and Muffler, 1971). 
positive magnetic anomalies of $10^{-8}$ to $10^{-7}$ teslas are apparently associated with five small thyolite domes of Quaternary age. Muffler and White (1969) report a K-Ar date of less than 55,000 years, with a best estimate of 16,000 years, for one of these (Obsidian Butte, see Fig. 4). The petrology and petrogenesis of these volcanoes were described by Robinson et al. (1976). The SSGS is also the locus of low electrical resistivity and high microseismicity. These phenomena and other aspects of the geophysics of the SSGS were reviewed by Younker et al. (1982) and by Elders and Cohen (1983).

The existence of the SSGS has been known for a long time. In 1540, only 48 years after Columbus' epic voyage, Melchor Dias followed the Gulf of California northward and penetrated overland into the delta of the Colorado until turned back by "fields of boiling mud" (Pourade, 1971). This must have been either the boiling springs, fumaroles, and mud volcanoes at Cerro Prieto or those that formerly existed near Mullet Island, one of the five rhyolite domes in the SSGS (Fig. 4). The SSGS hot springs were inundated in 1905- 6 by the rising lake that now forms the modern Salton Sea. These hydrothermal manifestations persuaded the Pioneer Development Co. in 1927 to drill three exploratory wells, up to $450 \mathrm{~m}$ deep, near Mullet Island (Lande, 1979). Although steam was encountered, these wells were never exploited for electrical power, and geothermal drilling was not resumed until 1957. Since then more than 50 commercial geothermal wells have been drilled. Although at present only two small geothermal electric power plants are operating in the SSGS, several more are under construction or planned. The slow pace of commercial development stems largely from the high costs of handling brines that, after steam separation, may have concentrations of up to $35 \%$ TDS.

In spite of this long history of development, resource assessments for the SSGS were, until recently, poorly constrained. At the lower end, Towes (1976) calculated the recoverable heat to be $11.7 \times 10^{18} \mathrm{~J}$, roughly equivalent to $50 \mathrm{MW}$ electrical for 30 years. At the higher end, Meidav and Howard (1979) estimated the recoverable heat as $586 \times 10^{18} \mathrm{~J}$, equivalent to about $20,000 \mathrm{MW}$ electrical for 30 years. In the light of newly acquired data from this project and from the numerous recently completed commercial wells, these estimates can now be refined and ideas on the hydrology of the SSGS improved.

Different investigators have proposed conflicting hydrothermal models for fluid flow in the SSGS. These models can be grouped as follows: (a) influx of cool groundwater from the southeast (Loeltz et al., 1975; Riney et al., 1978; Olson and Matlick, 1978); (b) influx of cool groundwater from the northwest (Rex, 1983); and (c) outflow of hot water southeast from the center of the SSGS (Kasameyer et al., 1984).

The major uncertainty in developing these models was that the data used were derived almost entirely from the landward portion of the SSGS; there were no significant drilling data for those parts of the gravity and magnetic anomalies now covered by the Salton Sea. This omission has since been remedied by the work of Newmark et al. (1986, 1988), whose new shallow temperature-gradient measurements now cover both the onshore and offshore parts of the system. They indicate a smaller area for the hottest part of the thermal anomaly than previously thought, with a region of shallow, high thermal gradients forming an 


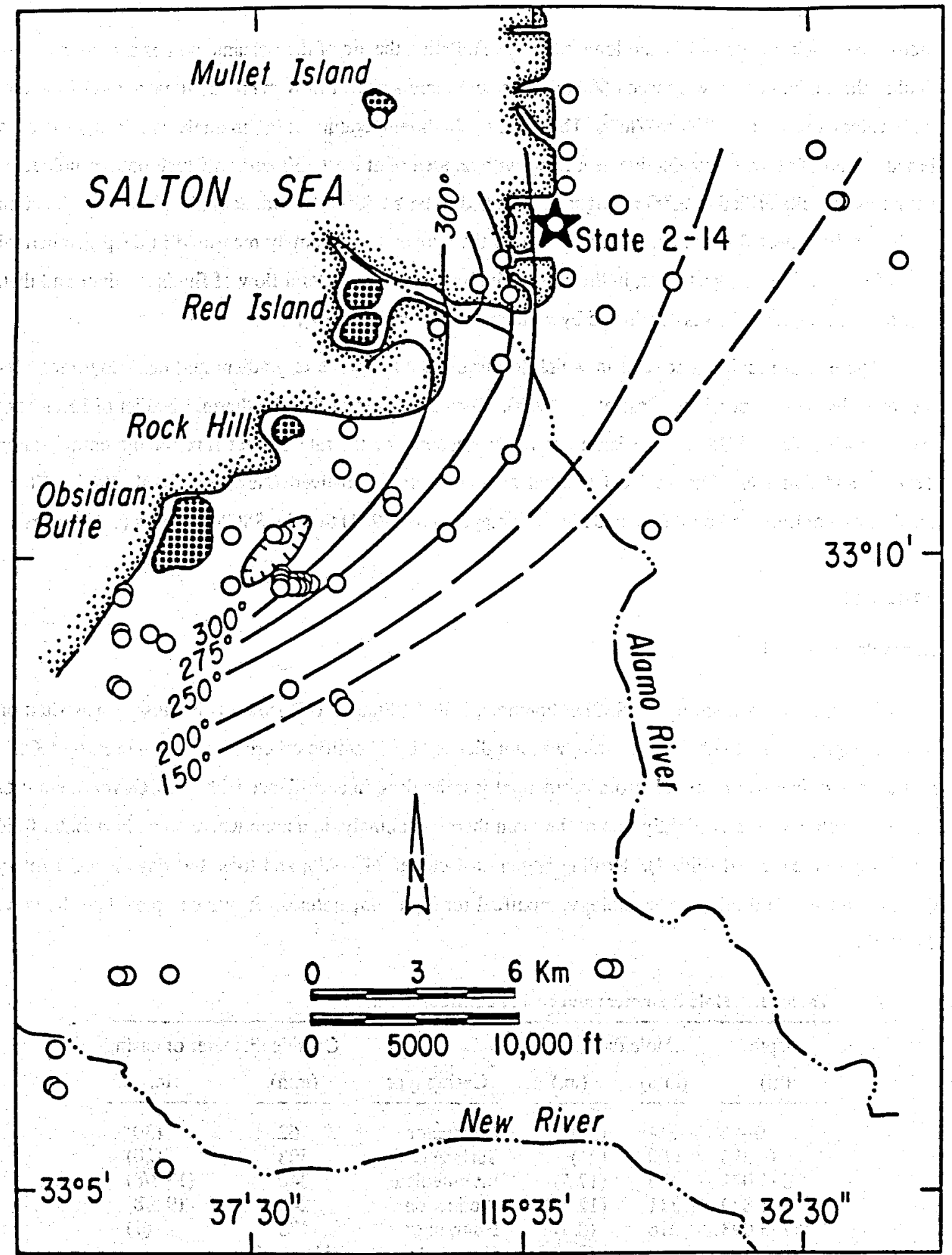

XBL 886-2373

Figure 4. Location of the borehole State 2-14 in the SSGS (star), and other geothermal wells (open circles). Cross-hatched areas are the Quatemary thyolite domes. The contours are isotherms in degrees centigrade measured in geothermal wells at $914 \mathrm{~m}(3,000 \mathrm{ft})$ depth. 
arcuate band $4 \mathrm{~km}$ wide and $12 \mathrm{~km}$ long, roughly paralleling the arc of the volcanic domes shown in Fig. 4 . Within this zone, heat flow exceeds $600 \mathrm{mWm}^{-2}$, and there are heat flow maxima, at each end of the arc, with values exceeding $1200 \mathrm{mWm}^{-2}$. This intense, high-temperature axial anomaly is surrounded by a broad region of elevated conductive heat flow, with an area of at least $150 \mathrm{~km}^{2}$, in which bottom-hole temperatures in wells drilled to $2500 \mathrm{~m}$ might be expected to be $\geq 250^{\circ} \mathrm{C}$ (Newmark et al., 1988). The location of this shallow heat-flow anomaly coincides with the temperature anomaly measured in deep geothermal wells (Fig. 4). This suggests that, in the zone of highest heat flow, lateral flow of fluids is minor and that, at greater depth, the SSGS is dominated by vertical fluid flow (Yi, 1987).

These data provide a context in which to discuss the temperature-gradient and heat-flow measurements in the SSSDP borehole (Sass et al., 1988). They also suggest that the thermal budget of local "hot spots" such as the SSGS may be large enough to account for the rate of heat flux for the entire Salton Trough, and that these intense local thermal anomalies are short-lived (Newmark et al. 1988). These results also confirm the inferences made by Kasameyer et al. (1984) that the SSGS is young ( $\leq 10^{4}$ years).

\section{THE SSSDP}

Borehole State 2-14

The specific location of the SSSDP borehole, called "State 2-14" (S/2-14) because it was sited on land belonging to the State of Califomia, was not dictated by scientific criteria, but was chosen by DOE's requesting competitive proposals from geothermal leaseholders, in accordance with U.S. Government procurement policies. It lies slightly east of the main thermal anomaly, in a zone where some horizontal fluid flow might be expected (Fig. 4). Drilling began on October 24, 1985, and took 160 days using a rotary drill rig and standard oil-field technology, modified for high temperatures. It was completed as shown in Table 1.

Table 1. Hole diameters and casing configuration.

\begin{tabular}{|c|c|c|c|c|c|}
\hline \multirow{2}{*}{$\begin{array}{c}\text { Depth } \\
\text { (m) }\end{array}$} & \multicolumn{2}{|c|}{ Hole diameter } & \multirow[b]{2}{*}{ Casing type } & \multicolumn{2}{|c|}{ Outside diameter of casing } \\
\hline & $(\mathrm{mm})$ & (in.) & & $(\mathrm{mm})$ & (in.) \\
\hline $\begin{array}{r}0-46 \\
0-315 \\
0-1,071 \\
0-1,829 \\
1,752-3,093 \\
3,093-3,193 \\
3,193-3,220\end{array}$ & $\begin{array}{l}914 \\
600 \\
445 \\
311 \\
216 \\
216 \\
156\end{array}$ & $\begin{array}{l}(36) \\
(26) \\
(17.5) \\
(12.25) \\
(8.5) \\
(8.5) \\
(6.125)\end{array}$ & $\begin{array}{l}\text { Conductor } \\
\text { Surface casing } \\
\text { Intermediate } \\
\text { Production } \\
\text { Hung liner } \\
\text { Open hole } \\
\text { Open hole }\end{array}$ & $\begin{array}{c}762 \\
508 \\
340 \\
245 \\
178 \\
\text { (Uncased) } \\
\text { (Uncased) }\end{array}$ & $\begin{array}{r}(30) \\
(20) \\
(133 / 8) \\
(95 / 8) \\
(7)\end{array}$ \\
\hline
\end{tabular}


Figure 5 is a time-depth plot summarizing the drilling progress and showing the amount of time allotted to various scientific activities (Sass and Elders, 1986). Because the primary goals of the SSSDP were scientific rather than commercial, research and development were given priority over engineering, to the extent that safety and borehole integrity were not compromised. However, problems were encountered that caused us to modify the science plan in practice. Attempts to mitigate these problems used up $\$ 1.3$ million of the budget for drilling and testing. These activities included fishing and stuck pipe (8 days), directional drilling (18 days), and lost circulation and well control (20 days) (Harper and Rabb, 1986). The highly fractured formations drilled caused directional problems below $1,071 \mathrm{~m}$. At 1,829 m depth, the borehole had deviated to the east at an angle of over $8^{\circ}$ from vertical. This required directional drilling between $1,853 \mathrm{~m}$ and $1,926 \mathrm{~m}$, which reduced the angle to an acceptable value of $3^{\circ}$ (Nicholson, 1986). Between $1,829 \mathrm{~m}$ and total depth, nine major fluid-loss zones, presumably fracture zones, caused slow progress (Table 2). While the drill string was being removed to change bits, these zones tended to allow brine to flow vigorously into the borehole and to boil. Aggressive treatment was necessary to quench the well and restore borehole integrity, using lost circulation materials and cement.

Cuttings and Core

At least $1 \mathrm{~kg}$ of cuttings was collected at $6-$ to $9-\mathrm{m}$ intervals to $900 \mathrm{~m}$ and at $3-\mathrm{m}$ intervals below that depth (except, of course, from zones of total circulation loss). Because the technology of continuous coring in large-diameter wells was not available to us, it was decided to allocate $\$ 1,000,000$ to spot coring. In

Table 2. Flow test results, State 2-14."

\begin{tabular}{|c|c|c|c|c|c|c|}
\hline $\begin{array}{l}\text { Well depth } \\
\text { (m) }\end{array}$ & $\begin{array}{l}\text { Depths } \\
\text { of flow } \\
\text { (m) }\end{array}$ & $\begin{array}{c}\text { Duration } \\
\text { (h) }\end{array}$ & $\begin{array}{l}\text { Flow } \\
\text { rate } \\
(\mathrm{t} / \mathrm{h})^{\mathrm{b}}\end{array}$ & $\begin{array}{l}\text { Wellhead } \\
\text { temp. } \\
\left.{ }^{\circ} \mathrm{C}\right)\end{array}$ & $\begin{array}{l}\text { Wellhead } \\
\text { pressure } \\
\text { (MPa) }\end{array}$ & $\begin{array}{l}\text { Enthalpy } \\
(\mathrm{kJ} / \mathrm{kg})\end{array}$ \\
\hline \multicolumn{7}{|l|}{ First test: } \\
\hline $\begin{array}{r}1,898 \\
\end{array}$ & 1,865 & $\begin{array}{r}4 \\
12 \\
2 \\
9\end{array}$ & $\begin{array}{r}273 \\
36 \\
195 \\
68\end{array}$ & $\begin{array}{l}205 \\
240 \\
210 \\
240\end{array}$ & $\begin{array}{l}14.0 \\
31.0 \\
15.5 \\
31.5\end{array}$ & $\begin{array}{l}930 \\
930 \\
930 \\
930\end{array}$ \\
\hline \multicolumn{7}{|l|}{ Second test: } \\
\hline 3,220 & $\begin{array}{l}1,865^{c} \\
2,012 \\
2,682 \\
3,193\end{array}$ & $\begin{array}{r}3 \\
24 \\
1 \\
4\end{array}$ & $\begin{array}{l}216 \\
127 \\
318 \\
136\end{array}$ & $\begin{array}{l}230 \\
245 \\
240 \\
255\end{array}$ & $\begin{array}{l}21.8 \\
31.5 \\
27.0 \\
34.0\end{array}$ & $\begin{array}{l}1,210 \\
1,115 \\
1,115 \\
1,050\end{array}$ \\
\hline
\end{tabular}

Adapted from Harper and Rabb, 1986.

Tonnes per hour.

Multiple flow zones. 


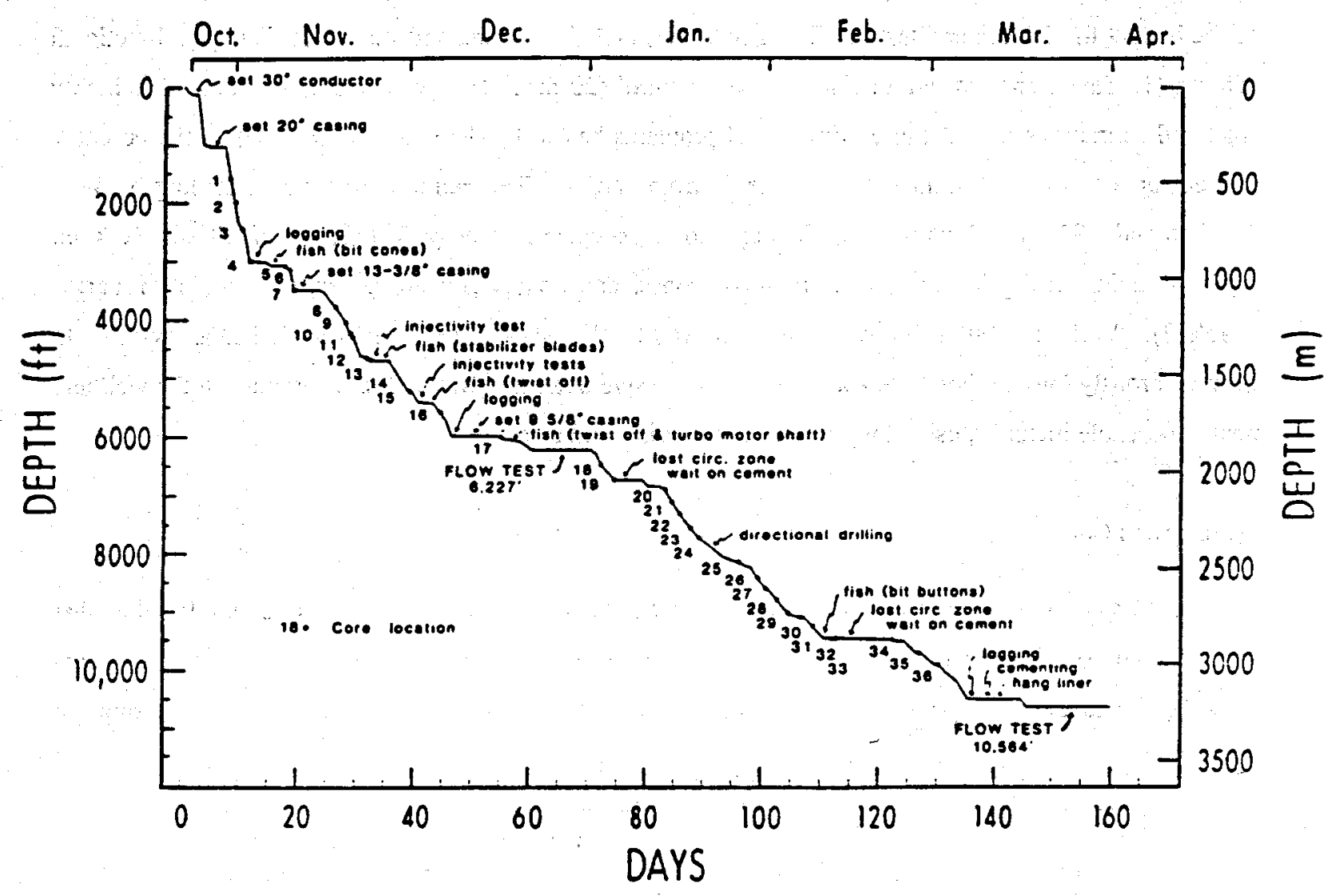

XBL $886-2374$

Figure 5. Depth-progress chart for the State 2-14 research borehole. The numbered dots record the locations of the drill cores. Note the large amount of time devoted to logging and testing $(6,227 \mathrm{ft}=1,898 \mathrm{~m}$; $10,564 \mathrm{ft}=3,220 \mathrm{~m})$. 
practice, only $\$ 550,000$ was spent on actual coring operations. The funds released were needed to address the problems mentioned above, and on additional rig time for wireline-logging. In 36 core runs, $241 \mathrm{~m}$ of the hole was cored and $224 \mathrm{~m}(93 \%)$ of core was recovered. At depths greater than $1,500 \mathrm{~m}$, the intervals that could be cored successfully declined precipitously due to the increased tendency of fractured rocks to jam the core barrel. Counting the $402-\mathrm{m}$ length of core barrels run, the $224 \mathrm{~m}$ of core obtained represents only 56\% of the potential core recovery (Nicholson, 1986). In view of the difficulties encountered here, using the best available oil-field technology and experienced personnel, we believe improvements are necessary in coring hot and fractured formations, particularly in large-diameter boreholes.

Fluid Sampling

Because variations of salinity were expected, fluid sampling was planned at $1 \mathrm{~km}, 2 \mathrm{~km}$, and at total depth. Unfortunately, no significant permeability was recognized between the casing points at $1,071 \mathrm{~m}$ and $1,829 \mathrm{~m}$. However, a major zone of circulation loss, associated with abundant vein-filling epidote, occurred at $1,865 \mathrm{~m}$. Accordingly the brine was stimulated to boil in the wellbore and allowed to discharge to a surface holding pond. A downhole temperature of $305 \pm 5^{\circ} \mathrm{C}$ was measured at $1,890 \mathrm{~m}$ during this flow (Table 2). Cost considerations precluded using a full-flow steam/brine separator or drilling a disposal well for the brine output.

When free of contamination by drilling fluid, the stable brine flow was expanded through a series of four orifice plates, and then flashed to the atmosphere (Michels, 1986a). An average chemical analysis of fluids sampled at the wellhead during the first flow test is shown in Table 3. Attempts were also made to collect unflashed samples using downhole samplers (Goff et al., 1987). When the brine storage pit, of approximately 7 million liters capacity, filled after one and a half days, the flow test was terminated. The brine was disposed of by injecting it back into the well before drilling resumed.

Budgetary limitations also prevented testing the numerous zones of lost circulation encountered below $1,865 \mathrm{~m}$. More than a million liters of drilling fluid were lost to these fractures. However, when circulation was again lost near the planned total depth, and temperature logs indicated that the loss was occurring at the bottom of the borehole, a 178-mm (7-in) liner was hung to $3,079 \mathrm{~m}$, without being cemented in place. The lack of cement in the annulus probably contributed to problems that occurred during the ensuing flow test, and to the eventual failure of the liner itself (see below). The borehole was then deepened to a total depth of $3,220 \mathrm{~m}$, to test the deeper part of the reservoir. During this second flow test, a temperature of $355 \pm 10^{\circ} \mathrm{C}$ was measured at $3,170 \mathrm{~m}$. Table 2 shows wellhead conditions during flow, and Table 3 shows an average chemical analysis corrected to preflash conditions. Once more, downhole fluid sampling was attempted. This flow test also had to end after two days when the storage pit filled. Unfortunately, this occurred before the produced fluids were completely free of contamination by mud and diesel oil, used 
Table 3. Average composition of produced fluids from State 2-14 borehole (corrected to pre-flash, downhole compositions).

\begin{tabular}{ccc}
\hline & & $\begin{array}{c}\text { Parts per million } \\
\text { (weight) }\end{array}$ \\
Substance & Dec. 1985 & Mar. $1986^{\mathbf{b}}$ \\
\hline $\mathrm{Na}$ & 52,661 & 52,200 \\
$\mathrm{Ca}$ & 26,414 & 27,100 \\
$\mathrm{~K}$ & 16,502 & 16,900 \\
$\mathrm{Fe}$ & 1,522 & 1,630 \\
$\mathrm{Mn}$ & 1,385 & 1,430 \\
$\mathrm{Zn}$ & 506 & 483 \\
$\mathrm{Si}$ & 2387 & 2560 \\
$\mathrm{Sr}$ & 405 & 401 \\
$\mathrm{NH}$ & 336 & 314 \\
$\mathrm{~B}$ & 253 & 258 \\
$\mathrm{Ba}$ & 194 & 336 \\
$\mathrm{Li}$ & 190 & 199 \\
$\mathrm{~Pb}$ & 95 & 97 \\
$\mathrm{Mg}$ & 36 & 47 \\
$\mathrm{Cl}$ & 153,668 & $-150,000$ \\
$\mathrm{SO}_{4}$ & 110 & 50 \\
$\mathrm{TDS}^{\mathrm{c}}$ & & \\
$\mathrm{CO}_{2}$ & 254,849 & 252,005 \\
$\mathrm{H}_{2} \mathrm{~S}$ & 1,664 & $-1,500$ \\
\hline
\end{tabular}

"First flow test, analysis, adapted from Michels, 1986b.

'Second flow test, unpublished data, A.E. Williams.

TDS = Total dissolved solids.

in drilling. Subsequently, temperature logs indicated that much of the flow came from behind the liner (see the discussion on temperture logging below).

The extent of residual contamination in the brine can be estimated from the hydrogen and oxygen isotopic analyses of A.E. Williams (personal communication, 1987), shown in Fig. 6. Coplen et al. (1975) had pointed out that the $\delta \mathrm{D}$ and $\delta \mathrm{O}^{18}$ of surface and shallow groundwaters in the Salton Trough plot to the right of the meteoric-water line and define an evaporation line connecting waters from the Colorado River to those from the Salton Sea. The averaged analyses for the second flow test lie on a mixing line between the averaged analyses for the first flow test and those of the drilling mud. The mud was mixed using local canal water, which plots close to Coplen's evaporation line. The isotopic data suggest that brine from the second test was 5-8\% contaminated by drilling fluid. 


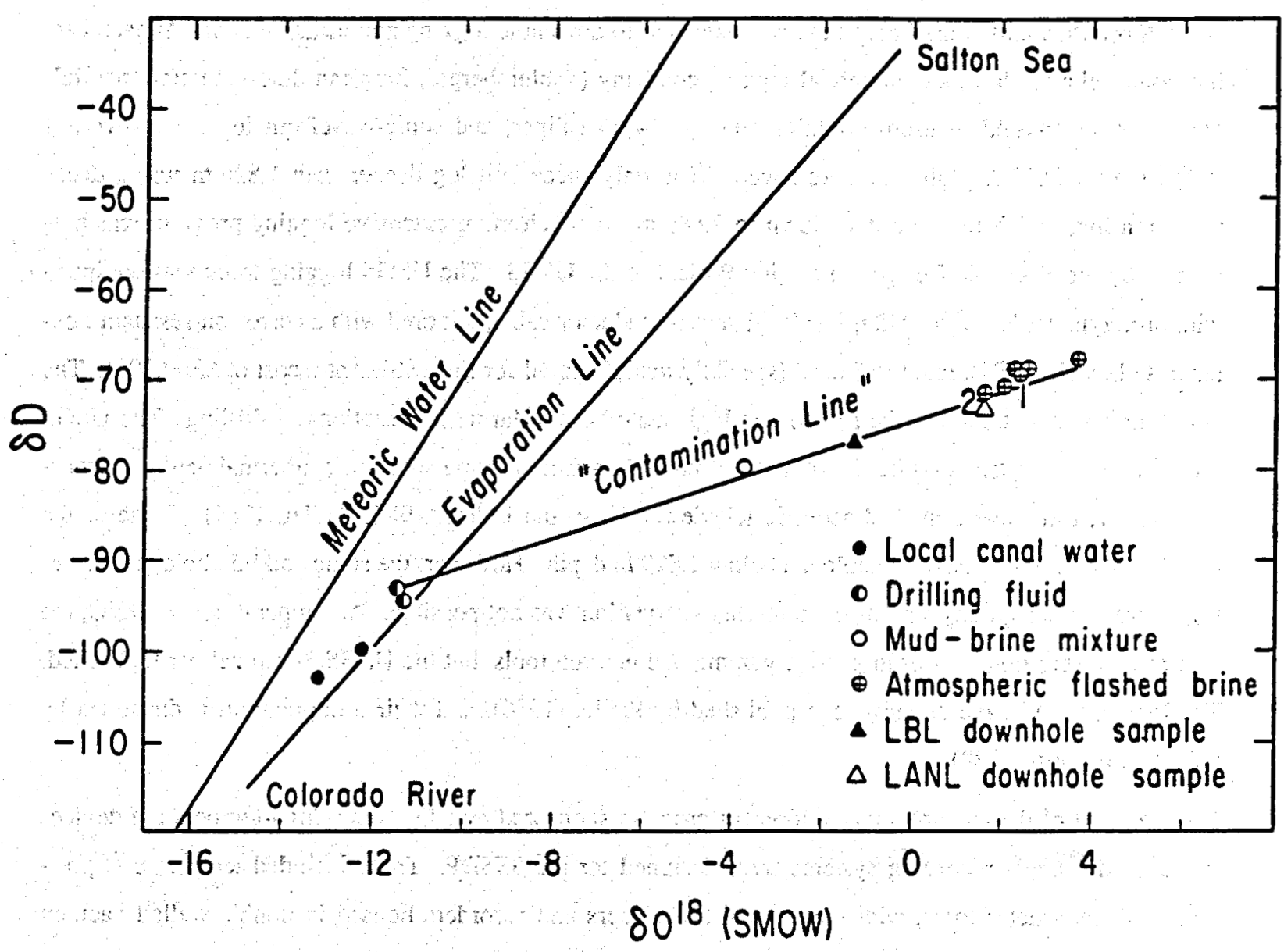

XBL $886-2376$

Figure 6. Hydrogen and oxygen isotopic ratios for fluids produced from the State 2-14 borehole and related samples, relative to the meteoric water line and the evaporation line for groundwaters in the Salton Trough of Coplen et al. (1975), connecting Colorado River waters to Salton Sea waters (see text). The drilling mud was made up using local canal water. " 1 " and " 2 " mark the average isotopic values of fluids produced from the first and second flow tests, respectively, calculated back to downhole conditions before boiling. The "Atmospheric flashed brine" samples were collected at the wellhead during the second flow test and have been made isotopically heavier by steam separation. Also shown are two samples collected by downhole samplers during the second flow test (LANL sample \#SS-21 and LBL sample \#SS-23), and a sample of mud-brine mixture from the initial flow of the well during this test. These data define a mixing or "contamination line," with fluids from the first flow test having negligible contamination (unpublished data of A.E. Williams). 
Downhole Logging and Geophysical Measurements

More than $\mathbf{4 5 0}$ hours of rig time were devoted to downhole logging and measurement. At each casing point below $315 \mathrm{~m}$, a commercial logging company (Schlumberger, Inc.) ran dual-induction, naturalgamma, compensated neutron-formation-density, 4-arm caliper, and sonic-waveform logs. However, at tempertures $>300^{\circ} \mathrm{C}$, problems were severe. The only successful log deeper than $1,829 \mathrm{~m}$ was a deepinduction log, which returned data down to $2,686 \mathrm{~m}$. A much more extensive logging program was performed by the Borehole Research Logging Project of the USGS. The USGS logging truck was equipped with prototype tools and a Teflon-insulated seven-conductor cable, armored with a corrosion-resistant nonferrous alloy (MP35N), rated to $315^{\circ} \mathrm{C}$ (specially manufactured for the SSSDP at a cost of $\$ 360,000$ ). The USGS unit was stationed at the site so that logs could be run during interruptions of drilling. The USGS logs obtained were temperature, 3-arm caliper, natural gamma, gamma spectral, epithermal neutron, acoustic velocity, full waveform, and acoustic televiewer (Sass and Elders, 1986; Paillet, 1986). Some of the USGS tools were successfully deployed below $1,829 \mathrm{~m}$ depth. However, the sonic and borehole televiewer logs were of poor quality so that fracture characterization was not possible. At temperatures $>300^{\circ} \mathrm{C}$, the best results were obtained from passive gamma and neutron tools, but the USGS 3-arm caliper tool failed. The logs obtained have already been published by Paillet (1986), and their interpretation is discussed by Paillet and Morin (1988).

As part of the technology-development program sponsored by DOE, other high-temperature devices that used downhole recording systems were designed for the SSSDP. These included temperature, pressure, and flow-meter tools, with mechanical transducers and recorders housed in double-walled vacuum heat shields (Dewars), designed to operate for up to 10 hours at temperatures up to $400^{\circ} \mathrm{C}$. In addition, a new continuously recording, digital pressure-temperature tool, built around a heat-shielded downhole electronic memory, was also deployed. This tool has considerable advantages over mechanical recording systems previously used at temperatures greater than $300^{\circ} \mathrm{C}$ (Carson, 1986; Sass et al., 1988).

Three different kinds of downhole fluid samplers, one mechanical, one powered by an electrical conductor cable, and one using a downhole battery pack as a power source, were deployed during flow tests (Solbau et al., 1986; Wolfenbarger, 1986). Out of 12 attempts, only one was completely and four partially successful in returning samples (Goff et al., 1987; Grigsby et al., 1987). The techniques of downhole sampling also require further development to sample fluids hotter than $300^{\circ} \mathrm{C}$. Other downhole experiments could only be carried out after cooling the well by injecting cold water. These included vertical seismic profiling, and experiments using a downhole gravity meter (Kasameyer and Hearst, 1987; Daley et al., 1988). 


\section{Temperature Logs}

Temperature logs were run during pauses in drilling operations, and during flow tests primarily for engineering purposes. After the borehole was shut in, a series of temperature profiles was measured to monitor the return to thermal equilibrium (Sass et al., 1988). The April 1, 1986 log records the situation immediately after injecting cooled brine from the second flow test (Fig. 7). This unexpected temperature profile is the key to understanding problems encountered during that test. The temperature inflections at $1.9 \mathrm{~km}, 2.6 \mathrm{~km}$, and $3.1 \mathrm{~km}$ show where cold brine entered the formation. Apparently, the uncemented liner did not isolate the lost-circulation zones penetrated during drilling. Most of the injected brine flowed up behind the liner, some even reaching the zone at $1,865 \mathrm{~m}$ that flowed in the first flow test. Apparently the lack of cement in the annulus of the liner compromised the second flow test so that these permeable zones contributed most of the flow produced in the second flow test (Table 2).

The latest logs show data only shallower than $1.8 \mathrm{~km}$ (Fig. 7). On May 29, 1986, it was found that the liner was blocked at about $1.9 \mathrm{~km}$. In June 1986 diagnostic logging revealed that the liner had corroded and parted at $1,883 \mathrm{~m}$. Presumably the type of liner chosen and the lack of cement in the annulus made it unsuitable for these hostile conditions. Below $1,883 \mathrm{~m}$, the best data are the bottomhole temperatures measured during the flow tests, i.e., $305^{\circ} \pm 5^{\circ} \mathrm{C}$ at $1,890 \mathrm{~m}$ and $355^{\circ} \pm 10^{\circ} \mathrm{C}$ at $3,170 \mathrm{~m}$. The curve marked "Equil. Temps." in Fig. 7 represents an equilibrium temperature profile, estimated by Sass et al. (1988). The extrapolated curve gives good agreement with the two bottomhole measurements (the short sections showing sharp excursions are computational artifacts in zones perturbed by brine injection).

\section{Remedial Actions and Future Work}

When the 7-inch (178-mm) diameter liner parted, only nine joints ( $82 \mathrm{~m}$, i.e., 270 feet) remained suspended from the production casing. When removed in August 1986, the collars on these joints were found $t o$ be moderately to severely cracked due to stress corrosion. Budgetary considerations caused further remedial work to be delayed until August 1987. Because the fallen liner could not be retrieved, the borehole was cemented off at $1,860 \mathrm{~m}$ and redrilling commenced, using downhole turbine motors to sidetrack past the old liner. Numerous technical difficulties caused this redrilling to be abandoned at only $2,188 \mathrm{~m}$ depth. In the summer of 1988 , DOE plans to carry out a 30-day-long reservoir-technology flow test of the open section of the redrilled borehole. Brine disposal will be by injection into a nearby well that was drilled by Kennecott, Inc., in September 1987. 


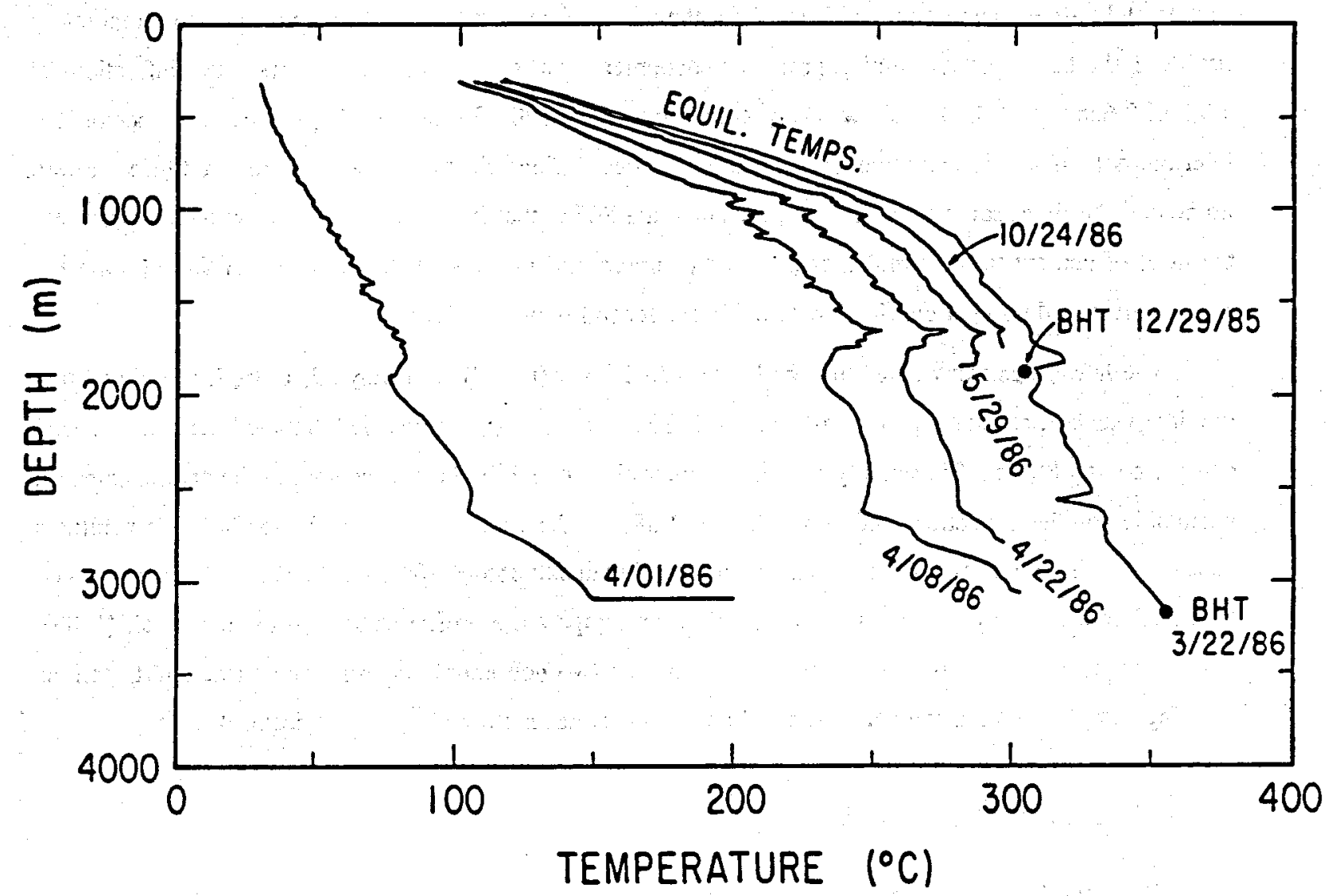

XBL 886-2375

Figure 7. Temperature profiles measured on various dates in the State 2-14 borehole. "BHT" represents bottom-hole temperatures measured during flow tests on the two dates shown. The profile marked "Equil. Temps." was extrapolated from the four previous temperature logs to the approximate equilibrium values by Sass et al. (1988). 


\section{SCIENTIFIC RESULTS}

Initial results of the intensive studies of samples and data recovered were reported in a symposium at the annual meeting of the American Geophysical Union in May 1987. Important findings from the resulting papers (including some not submitted to this issue) are briefly summarized here.

\section{Lithostratigraphy}

The borehole penetrated Pleistocene strata of the Borrego and Brawley Formations (Tarbet and Holman, 1944; Dibblee, 1955), with 70\% lacustrine mudstones and siltstones, and minor amounts of sandstones, deposited in lake-margin, channel-fill, and lacustrine delta environments (Herzig et al., 1988). To the depth of about $335 \mathrm{~m}$ these strata are unconsolidated; at greater depth they become progressively indurated and mineralized. Sandstone compositions indicate a provenance from the Colorado River. Steep bedding, minor faults, and liquefaction features are common, as expected in an area of high seismicity. Anhydrite is abundant as nodules, concretions, and thin beds, the product of an evaporitic environment.

Igneous Rocks

A 0.25 -m-long core of the lower contact of a silicic volcanic tuff was recovered from $1,704 \mathrm{~m}$. Based on geophysical logs its thickness may be between one and two meters. As far as we are aware, this is the first published report of a subsurface pyroclastic rock from the Salton Trough. Diabasic sills at 2,880-2,883 and 2,895-2905 $\mathrm{m}$ depth have brecciated chilled contacts with the hydrothermally altered shales. Chemical data suggest that the silicic tuff is correlative with a tuff cropping out $25 \mathrm{~km} \mathrm{NW}$ in the Durmid Hills. This in tum is apparently derived from the Bishop tuff erupted $0.7 \mathrm{~m}$.y. ago from the Long Valley caldera, California (Herzig and Elders). It may prove to be a useful marker bed to comrelate between geothermal wells. However, the diabase intrusions seen in the $S / 2-14$ borehole are part of a bimodal thyolite-basalt assemblage, previously observed in the Salton Butte volcanics in the SSGS (Robinson et al., 1976). The diabases appear to be representatives of larger basaltic intrusions that are the probable source of the large magnetic anomaly; rhyolites have much too low magnetic susceptibility (Griscom and Muffer, 1971). Such basaltic intrusions are the most likely heat source for the SSGS. The diabases, although somewhat enriched in light rare-earth elements relative to the basalts of the East Pacific Rise, probably had a mantle-derived parent magma, appropriate for a rift system (Herzig and Elders, 1988).

Metamorphism

With increasing depth, the sediments become progressively more metamorphosed and exhibit homfelsic textures. Earlier workers had described this progressive metamorphism of up to greenschist facies in 
the SSGS, in samples recovered from geothermal wells (Muffler and White, 1969; McDowell and Elders, 1980, 1983). This earlier work was based almost entirely on study of drill chips. Thus it was difficult to elucidate paragenetic sequences and sometimes even to distinguish between detrital, authigenic, and vein minerals. Study of cores from the borehole S/2-14 has reduced many of these uncertainties. The sequence of prograde mineral reactions in the cores has also clearly demonstrated a transition into amphibolite facies, at temperatures and pressures much lower than generally accepted for that degree of metamorphism (Turner, 1986).

In the sandstones, metamorphic zones observed with increasing grade include a chlorite-calcite zone $(610-2,480 \mathrm{~m})$; a biotite zone $(2,480-3,000 \mathrm{~m})$; and a clinopyroxene zone $(3,000-3,180 \mathrm{~m})$ (Cho et al., 1988). Authigenic epidote, quartz, and albite are ubiquitous below $900 \mathrm{~m}$. In the clinopyroxene zone, the coexistence of authigenic actinolite, actinolitic homblende, and oligoclase demonstrates the transition from greenschist to amphibolite facies. In the mudstones, progressive changes in the phyllosilicates include authigenic illite/smectite mixed layers being replaced by illite at $1,222 \mathrm{~m}$, illite/chlorite appearing at $1,582 \mathrm{~m}$, chlorite/biotite at $2,480 \mathrm{~m}$, and biotite at $3,175 \mathrm{~m}$ (Donaghe and Peacor, 1987). Extensive reactions between brines and carbonates in both sandstones and mudstones release $\mathrm{CO}_{2}$ by reactions forming epidote, actinolite, and diopside. Such extensive chemical interaction is also indicated by progressive leaching of $\mathrm{Cu}, \mathrm{Zn}$, and $\mathrm{Mn}$ and enrichment of $\mathrm{Sr}$ in these rocks (Shearer et al., 1988).

The S/2-14 borehole occupies a flank position in the geothermal field (Fig. 4). As might be expected, therefore, its petrology shows transitional characteristics relative to that of geothermal wells in the center of the field. Cuttings from geothermal wells in the center of the SSGS show similar metamorphic zonation but at shallower depth, and exhibit higher degrees of leaching of $\mathrm{Mn}, \mathrm{Cu}, \mathrm{Zn}$, and other metals, particularly in the biotite zone. These differences suggest that hydrothermal alteration in the central portion of the SSGS has been more extensive (involving a higher water/rock ratio), has been of longer duration, or both (McDowell, 1987).

Rock fragments ejected from the borehole during the first flow test, when compared with cores above and below the production zone at $1,865 \mathrm{~m}$, demonstrate an intense epidote enrichment in the vicinity of open fractures. The fracture-filling minerals consist of an open framework of acicular epidote with pyrite, or acicular epidote with specular hematite. Thermodynamic analyses of solid phases and brine from the first flow zone are generally consistent with the major mineral assemblages in the flow zone at $300^{\circ} \mathrm{C}$ (Charles et al., 1988). However, the fluid is not in equilibrium with the pyrite-bearing assemblages. Oxidation of pyrite-bearing metasediments seems to have leached sulfur from these rocks, stabilizing the hematite-bearing assemblages. 
Origin of the Brine

The origin of the salt in the SSGS brines has been attributed to dissolution of lacustrine evaporites, formed from evaporated Colorado River water, by percolating groundwater (White, 1968; Rex, 1983). Studies of newly available drill cores now provide the first direct physical evidence for dissolution of nonmarine evaporites. These cores contain recrystallized, metamorphosed, bedded anhydrite and anhydritecemented shale breccias, which appear to have formed by solution collapse. Some fluid inclusions within these anhydrites contain up to $50 \%$ of crystals of halite, sylvite, and carbonates in a Na-Ca-K-Cl brine, and have homogenization temperatures of $300^{\circ} \mathrm{C} \mathrm{(McKibben} \mathrm{et} \mathrm{al.,} \mathrm{1988b).} \mathrm{These} \mathrm{observations} \mathrm{are} \mathrm{con-}$ sistent with trapping of salt-saturated brines during dissolution of evaporites by hydrothermal fluids.

Comparison of the data from S/2-14 with that from other wells in the SSGS have led Williams and McKibben (1987) and McKibben et al. (1987) to point out the bimodal character of the SSGS fluids. The hot, hypersaline brine of the type described in Table 3 is overlain by a cooler $\left(<250^{\circ} \mathrm{C}\right)$, metal-poor fluid of lower salinity (< $12 \%$ TDS). A sharp interface between these two fluid types exists over much of the field. This interface has a domal structure roughly paralleling the isotherms but transgressing the bedding and other structures. Williams and McKibben (1987) suggest that this dome formed by advective rise of heated hypersaline brine as a brine diapir. Furthermore, chemical reactions between brines and rocks, especially those involved in ore formation, are; to a large degree, controlled by this abrupt brine interface (McKibben et al., 1987). These conclusions are complemented by extensive geochemical investigations of the brines (Campbell et al., 1987; Michels, 1988; Thompson and Fournier, 1988).

Ore Formation

Active ore formation had earlier been described in the SSGS in studies based primarily on drill cuttings (Skinner et al., 1967; McKibben and Elders, 1985). The cores from S/2-14 show that ore minerals are almost entirely restricted to mineralized fractures and the adjacent rocks. These samples have greatly clarified the mineral parageneses (McKibben et al., 1987; Caruso et al., 1988). An carlier carbonate-sulfide vein set contains minor epidote, adularia, ankerite together with abundant calcite, sphalerite, pyrite, chalcopyrite, galena, and pyrnhotite. A later, more open silicate-hematite-sulfide vein set consists of epidote, quartz, chlorite, and abundant hematite, together with chalcopyrite, pyrite, sphalerite, and galena. The later set is apparently forming today. Further insight into this mineralization comes from fluid-inclusion studies (Andes, 1987; Roedder and Howard, 1988) and light stable isotopic studies (Sturtevant and Williams, 1987). These indicate a complex thermal history in S/2-14, with somewhat higher paleotemperatures and much lower paleosalinities in the upper $1 \mathrm{~km}$ than those observed today at greater depths. This complex history included fracturing and infiltration by fluids of varying composition and temperature that sealed the fractures by mineral precipitation. The vein mineral assemblages observed suggest that cooler, oxidized 
fluids have displaced hotter, reduced fluids as brines derived from different sources mixed (McKibben et al., 1988a).

Earlier isotopic studies of $\mathrm{Sr}$ and $\mathrm{Pb}$ suggested that the source of these components in the brines of the SSGS was leaching from the host rocks (Doe et al., 1966). Whole-rock chemical analyses of the S/2-14 cores lead to the conclusion that the other metals in the brine are also leached from the sediments (Shearer et al., 1988). Earlier studies of the base-metal sulfide ores in the SSGS, using available drill cuttings, suggested that the source of their sulfur was replacement of diagenetic stratabound pyrite by $\mathrm{Cu}, \mathrm{Pb}$, and $\mathrm{Zn}$ from the metal-rich brines (McKibben and Elders, 1985). Petrographic studies of the S/2-14 cores and analyses of sulfur isotopes now indicate that the source of sulfur in the hydrothermal sulfides of the SSGS is sedimentary. However, the reduced sulfur is derived by reduction of sulfates in the host evaporites (McKibben and Eldridge, 1988).

\section{Radiochemistry}

Study of strong disequilibria of daughter products in the ${ }^{238} \mathrm{U},{ }^{235} \mathrm{U}$, and ${ }^{232} \mathrm{Th}$ radioactive-decay chains is providing new insights into the mechanisms controlling radioisotope exchange and permits estimation of the rates of brine-rock interaction (Zukin et al., 1987; Hammond et al., 1988). In the case of the short-lived isotopes ${ }^{228} \mathrm{Ac} /{ }^{228} \mathrm{Ra}$, the data indicate that the mean lifetime of relatively insoluble actinides in solution, before removal from the brine by sorption on solid surfaces, is about two hours. ${ }^{212} \mathrm{~Pb} / 24 \mathrm{Ra}$ and ${ }^{210} \mathrm{~Pb} / 26 \mathrm{Ra}$ ratios in the brine are comparable to ratios predicted from a simple recoil model. The mean residence times of lead and radium in solution are both only about 30 years, whereas the corresponding residence time of radium in associated solid phases is about 2,000 years (Hammond et al., 1988, this issue). The implications of these observations are that the SSGS is very young and that chemical-exchange rates are very rapid.

Geophysics

Apart from the temperature measurements already discussed, geophysical studies stressed the variation of physical properties within the borehole, both from downhole measurements (Kasameyer and Hearst, 1987; Paillet and Morin, 1988; Daley et al., 1988) and from laboratory measurements (Lin and Dailey, 1988; Tarif et al., 1988). Downhole estimates of porosity, density, and seismic velocity were in reasonable agreement with laboratory determinations. The downhole gravimetric measurements of density (Kasameyer and Hearst, 1987) are in good agreement with the well-log values (Paillet and Morin, 1988, this issue) but are slightly higher. Vertical seismic profiling (Daley et al., 1988, this issue) provided a compressional-wave velocity profile comparable to that obtained from full-waveform velocity logs by Paillet and Morin (1988). They also inferred anisotropy in shear-wave velocity on the order of about $1 \%$ at 
this site. A fracture zone at depths of between 2.0 and $2.1 \mathrm{~km}$ provided a strong reflector, and other fracture zones were detected on the basis of P-wave scattering.

Depth-smoothed trends in electrical, acoustic, and gamma attenuation logs recorded changes in the properties of clay minerals with temperature (Paillet, 1986; Lei, 1988; Paillet and Morin, 1988). Local departures from this trend occur due to brine conduction in porous sands, which overwhelms clay mineral conductivity. Below $1.8 \mathrm{~km}$ the induction and epithermal neutron logs confirmed the nearly uniformly impermeable nature of the altered sediments, due to reduced porosity. However, the frequent lostcirculation zones indicate increasing fracture permeability with depth. Neither passive gamma logs nor electrical-resistivity logs could be interpreted with great confidence below $1.8 \mathrm{~km}$ because of a generally low level of radioactivity, high salinity, and low porosity. Televiewer logs were also of limited value in fracture mapping, owing primarily to the fact that the hole was greatly enlarged and contained significant amounts of cement and lost-circulation material in the zones of greatest interest (Paillet, 1986; Paillet and Morin, 1988).

\section{Ongoing Studies}

Many of the studies reported in this special issue will continue for some time. It seems appropriate, however, to mention some of the things that are not underway and which should be done, or that have not yet been sufficiently applied. Perhaps the most significant omissions are the areas of sedimentology, stratigraphy, and paleontology. While the cores are a treasure trove for petrologists and economic mineralogists, much more could be done, building on the work of Herzig et al. (1988) to develop sedimentological information in terms of the source and provenance of the sediments, the depositional environment, the soft-sediment deformation, and the earthquake-induced clastic dikes. More could be done to correlate the sedimentological, petrological, and wireline-log properties of the altered sediments.

As yet, we know of no attempts to provide age control on these sediments. Are there hardy microfossils that survive above $200^{\circ} \mathrm{C}$ and are there hardy micropaleontologists willing to look for them? However, work is underway to attempt radiometric dating of the S/2-14 wuff and the Pleistocene tuff in the Durmid Hills, which Merriam and Bischoff (1975) correlated with the Bishop tuff enupted from Long Valley caldera, California, 0.72 m.y. ago.

Similarly, it would be highly desirable to extend and improve attempts at dating the hydrothermal system and its igneous rocks by radiometric or other means. Comparisons with the Cerro Prieto geothermal system (Fig. 1), which has a similar lithology to the SSGS, would be also worthwhile. Whereas the Cerro Prieto system has comparable temperatures and similar hydrothermal minerals to those of the SSGS, there are striking differences (Schiffman, et al., 1984). In contrast to the SSGS, the occurrence of hydrothermal minerals at Cerro Prieto is incipient, and the rocks largely retain their sedimentary textures. In addi- 
tion, ore minerals and mineralized veins are scarce at Cerro Prieto. Determining the cause of the differences would improve our understanding of both systems. The detailed information from S/2-14 should also be correlated with the information available from the other wells in the area, to generate threedimensional quantitative models for the origin and evolution of the SSGS, such as has been done for Cerro Prieto (e.g., Elders et al., 1984). In future phases of the SSSDP, deeper research wells should be sited in the center of the thermal zone closer to the heat sources responsible for the geothermal system, and perhaps even to reach molten rock.

\section{CONCLUSIONS}

Phase 1 of the SSSDP met or exceeded almost all of its initial objectives. The fruitful collaboration that occurred among several government agencies and researchers from various universities and organizations augurs well for the future of continental scientific drilling in the U.S.A. Although organizational and technical problems were encountered, we produced a wealth of new data, under hostile conditions, concerning a dramatic example of active metamorphism and ore genesis. We also showed that, although the rocks in the SSGS become increasingly indurated with depth and lose porosity, permeability increases due to fracturing. This suggests that the resource potential of the SSGS may be increased by drilling deeper wells.

We also learned some lessons applicable to other scientific drilling projects. One lesson, as the new shallow-temperature-gradient data from the SSGS have shown, is the utility of combining both shallow and deep drilling. In a scientific drilling investigation, we should not become wedded to any specific depth as the key to success.

A lesson specifically applicable to the study of hydrothermal systems is the importance of arranging long-term flow tests of specific production zones. The very successful two-day flow test at $1,859 \mathrm{~m}$ sampled brine relatively free of drilling-fluid contamination. Several conditions contributed to this success: there were no major losses of circulation higher in the well; drilling was discontinued soon after encountering the loss zone at $1,859 \mathrm{~m}$; and the volume of the brine-holding pond was adequate to allow the flow to clean up. However, the short duration of the test meant that the well was always in a transient stage of flow. The flow test of the deepest producing horizon at 3,193 m encountered numerous problems, because none of the conditions mentioned above were met. We believe therefore that it is desirable, in testing geothermal systems, to: (a) isolate specific permeable zones; (b) flow the well long enough to remove contamination; (c) sample successively larger volumes of the reservoir; and (d) establish stable conditions for adequate reservoir characterization. This requires that a disposal well should be available and also suggests the need to develop high-temperature packers and drill-stem test equipment. Another lesson was the difficulty of dealing with zones of massive loss of circulation. Normally in drilling commercial wells, we 
look for permeability rather than try to overcome it.

Perhaps the most important lesson leamed from the SSSDP is to obtain as much core as possible. Due to the fractured nature of the rocks, the $7 \%$ of the well that was cored was less than the $10 \%$ called for in initial planning. The amount of core recovered was, however, comparable to that obtained by other recent Continental Scientific Drilling projects using rotary rigs. These cores have provided unprecedented research opportunities relative to what is normally available from commercial geothermal wells. They allowed us to (a) make petrophysical measurements, (b) identify sedimentary and evaporitic facies, (c) determine some of the structural relations, (d) distinguish among igneous tephras, sills, and flows, and (e) resolve mineral parageneses and vein sequences, and study the birth of an ore body. Better coring systems obviously need to be developed, especially for deep hot wells and fractured formations.

In spite of the large investments in equipment and rig time, the results of the wireline-logging program were disappointing for depths greater than $1.8 \mathrm{~km}$. The tools deployed by the USGS were prototypes, developed some years ago, that were pushed beyond their temperature limits. Hole conditions precluded optimum tool performance in the most interesting depth intervals. Because of the need to obtain good quality wireline logs in deep boreholes that are not continuously cored, the present generation of logging tools and cables needs to be upgraded as regards temperature, performance, and reliability for future research drilling projects.

As mentioned earlier, the DOE sponsored the development of several downhole recording ("slickline") tools that provided useful data for the SSSDP. The downhole samplers, although plagued initially with component failures attributable to the hostile environment, demonstrated they could work at $355^{\circ} \mathrm{C}$. Similarly, the heat-shielded, mechanical-recording pressure-temperature tools operated without the failures associated with conventional mechanical tools above $300^{\circ} \mathrm{C}$. However, the most significant advance in logging technology was the heat-shielded digital temperature tool. This has higher accuracy and more rapid response than a mechanical tool (10 seconds versus 10 minutes), thus providing a much higher data density. Such digital tools seem to offer a great potential for future development and do not require expensive conductor cables.

Probing deeper into the roots of hydrothermal systems will require more costeffective solutions to the kinds of problems we faced in drilling, sampling, and logging than were available to us. We have leamed that drilling and testing at high temperatures is just as much a technical and scientific frontier as drilling at very great depths. However, as the Continental Scientific Drilling Program drills deeper, even in areas of moderate geothermal gradient, conditions comparable to those at lesser depths in geothermal systems will inevitably be encountered. Thus the accumulated experience of drilling and testing by the worldwide geothermal industry will become more generally applicable. 
The science of geology developed in the nineteenth century by painstaking mapping of the surface of the continents. In the first half of this century geophysical methods began to play an increasing role in our understanding of the crust of the earth. Twenty years ago geology was revolutionized by the new systematic study of the ocean floors by the Deep Sea Drilling Project. In retrospect, it seems paradoxical to us that, although continental geology is inherently more complex, in the U.S.A. we have had, until recently, no scientific drilling program on land comparable to the ocean drilling program. Our experience with the Salton Sea Scientific Drilling Project has convinced us of the importance of such a program in the United States.

\section{ACKNOWLEDGEMENTS}

This project, which was funded by DOE, USGS, and NSF, succeeded by the wholehearted cooperation of many individuals too numerous to mention here. We are particularly grateful to John Hendricks, Sue Priest, and Lori Robison, whose efforts as on-site science managers always exhibited the highest degree of professionalism and congeniality. We are also appreciative of the support of our colleagues at UCR and USGS. We are indebted to A.E. Williams for providing unpublished data on fluid chemistry and to F.L. Goff, J. Eichelberger, LJ.P. Muffler, and R.H. Wallace, Jr., for penetrating reviews of earlier drafts of this manuscript. The Chief Scientist position for the SSSDP was funded by NSF grant EAR 8303557. The on-site science-management team was supported by the Office of the Chief Geologist, USGS. This is IGPP/UCR Report Number 88-1.

\section{REFERENCES}

Adduci A.J., D.W. Klick, and R.H. Wallace Jr., Management of the Salton Sea Scientific Drilling Program. Trans. Geothermal Resources Council, 10, 445-448, 1986.

Andes J.P. Jr., Mineralogic and fluid inclusion study of ore-mineralized fractures in drillhole State 2-14, Salton Sea Scientific Drilling Project, Imperial Valley, Califomia. UCR-IGPP Rep. 87/17. M.S. Thesis, Inst. Geophys. and Planet. Phys., Univ. of California, Riverside, 136 pp. 1987.

Biehler S., Bouguer Gravity Map of California, Salton Sea Sheet. Calif. Division of Mines and Geology, 1974.

Biehler S.S., R.L. Kovach, and C.R. Allen, Geophysical Framework of the Northem End of the Gulf of California Structural Province. Am. Assoc. Petroleum Geol. Memoir 3, 126-143, 1964.

Campbell A.C., J.M. Edmond, T.S. Bowers, C.I. Measures, M.R. Palmer, and E.T. Brown, Geochemistry of Salton Sea Scientific Drilling Project Hydrothermal Fluids in Comparison to Red Sea Brines. Abs., EOS Trans. AGU, 68, $439,1987$.

Carson C.C., Development of downhole instruments for use in the Salton Sea Scientific Drilling Project. Trans. Geothermal Resources Council 10, 449-454, 1986.

Caruso L.J., D.K. Bird, M. Cho, and J.G. Liou, Epidote - mineralized fractures in the CS 2-14 Well: Implications on Hydrothermal Fluid Composition. J. Geophys. Res., this issue, 1988.

Charles R.W., D.R. Janecky, F.E. Goff, and M.A. McKibben, Chemographic and Thermodynamic Analysis of the Paragenesis of the major phases in the vicinity of the $6,120 \mathrm{ft}(1,866 \mathrm{~m})$ Flow-Zone, California State 2-14. J. Geophys, Res., this issue, 1988. 
Cho M.; J.F. Liou, and D.K. Bird, Prograde Phase Relations in the C.S. 2-14 Well metasandstones, Salton Sea geothermal field, California. J. Geophys. Res., this issue, 1988.

Coplen T.B., P. Kolesar, R.E. Taylor, C. Kendall and C. Mooser, Investigations of the Dunes geothermal anomaly, Imperial Valley, Califomia: Part IV, Geochemical studies of water, calcite, and silicates. UCR-IGPP Rep. 75/20, Inst. Geophys. and Planet. Phys., Univ. of California, Riverside, 43 pp., 1975.

Daley T.M., T.M. McEvilly, and E.L. Majer, Analysis of P- and S-wave VSP data from Salton Sea Scientific Drilling Project. J. Geophys. Res., this issue, 1988.

Dibblee T.W. Jr., Geology of the Imperial Valley region, California, Geology of the Natural Provinces, Chapter 2. Geology of Southern Califomia, edited by R.H. Jahns. Calif. Div. Mines Bull., 170, 21-28, 1954.

Doe B.R., C.E. Hedge, and D.E. White, Preliminary investigation of the source of lead and stromtium in deep geothermal brines underlying the Salton Sea geothermal area. Econ. Geol. 61, 462-483, 1966.

Donaghe L.L., and D.R. Peacor, Textural and mineralogic transitions in SSSDP argillaceous sediments (1987). Abs., EOS Trans. AGU, 68, 454, 1987.

Doser D.I., and H. Kanamori, Depth of seismicity in the Imperial Valley region (1977-1983) and its relationship to heat flow, crustal structure, and the October 15, 1979 earthquake. J. Geophys. Res., 91, 675-688, 1986.

Elders W.A., Continental Scientific Drilling in California: The saga of the Salton Sea Scientific Drilling Project (SSSDP). Trans. Geothermal Resources Council, 9, 107-112, 1985.

Elders W.A., and S. Biehler, Gulf of Califomia Rift System and its Implications for the Tectonics of Western North America. Geology, 3, 85, 1975.

Elders W.A., and L.H. Cohen, The Salton Sea Geothermal Field, Califomia as a near-field natural analog of a radioactive waste repository in Salt. Report BMI/ONWI-513, Office of Nuclear Waste Isolation. 138 pp., 1983.

Elders W.A., R.W. Rex, T. Meidav, P.T. Robinson, and S. Biehler, Crustal spreading in southern California: The Imperial Valley and the Gulf of California formed by rifting apart of a continental plate. Science, 178, 15-24, 1972.

Elders W.A., A.E. Williams, D.K. Bird, and P. Schiffman, Hydrothermal flow regime and magmatic heat source of the Cerro Prieto geothermal system, Baja California, Mexico. Geothermics, 13, 27-47, 1984.

Fuis G.S., W.D. Mooney, J.H. Healey, G.A. McMechan, and W.J. Lutter, Crustal structure of the Imperial Valley. U.S. Geol. Survey. Prof. Paper 1254, 25-49, 1982.

Fuis G.S., W.D. Mooney, J.H. Healey, G.A. McMechan, and W.J. Lutter, A seismic refraction survey of the Imperial Valley region, Califomia. J. Geophys. Res., 89, 1165-1189, 1984.

Goff F., L. Shevnall, C.O. Grigsby, and B. Dennis, Downhole fluid sampling at the SSSDP California State 2-14 well, Salton Sea, Califomia. Rep. LA-11052-OBES, 32 pp., Los Alamos National Laboratory. 1987.

Grigsby C.O., F. Goff, L. Shevenell, J. Archuleta, J. Cruz, P.E. Trujillo, D. Counce, and G.K. Bayhurst, Downhole fluid sampling and analytical data for the SSSDP well, Salion Sea, California. Abs., EOS Trans. AGU, 68, 454, 1987.

Griscom A., and L.PJ. Muffler, Aeromagnetic Map and Interpretation of the Salton Sea Geothermal Area, Califomia. Geophysical Investigations Map, GP 754, U.S. Geol. Survey, 1971.

Hammond D.E., J.G. Zukin, and T-L. Ku, The kinetics of radioisotope exchange between brine and rock in a geothermal system. J. Geophys. Res., this issue, 1988.

Harper C.A., and D.T. Rabb, The Salton Sea Scientific Drilling Project Drilling Summary. Trans. Geothermal Resources Council, 10, 455-460, 1986.

Helgeson H.C., Geologic and thermodynamic characteristics of the Salton Sea geothermal system. Amer.J. Sci., 266, 129-166, 1968.

Herzig C.T., and W.A. Elders, Igneous rocks in the State 2-14 research borehole, Salton Sea Scientific Drilling Project, California, U.S.A. J. Geophys. Res., this issue, 1988.

Herzig C.T., J.M. Mehegan, and C.E. Selting, Lithostratigraphy of an active pull-apart basin: Salton Sea Scientific Drilling Project. J. Geophys. Res.; this issue, 1988. 
Johnson C.E., and D.P. Hill, Seismicity in the Imperial Valley. U.S. Geol. Survey. Prof. Paper 1254, pp. 15-24, 1982.

Kasameyer P.W., and J.R. Hearst, Borehole gravity measurements in the SSSDP hole Abs., EOS Trans. AGU, 68, 445, 1987.

Kasameyer P.W., L.W. Younker, and J.M. Hanson, Development and application of a hydrothermal model for the Salton Sea geothermal field, California. Geol. Soc. Am. Bull, 95, 1242-1252, 1984.

Lachenbruch A.J., J.H. Sass, and S.P. Galanis, Heat flow in southernmost California and the origin of the Salton trough. J. Geophys. Res., 90, 6709-6736, 1985.

Lande D., History of Drilling in the Imperial Valley, in Geology and Geothermics of the Salton Trough, edited by W.A. Elders, Campus Museum Contributions, No. 5, Univ. of California, Riverside, pp. 45-46, 1979.

Lei H.-Y., Porosity and hydrothermal alteration determined from wireline logs from the Salton Sea geothermal field, California, U.S.A. UCR-IGPP Rep. 88/5, M.S. Thesis, Inst. Geophys. and Planet. Phys., Univ. of California, Riverside, 168 pp., 1988.

Lin W., and W. Dailey, Laboratory Determined Transport Properties of Core from the Salton Sea Scientific Drilling Project. J. Geophys. Res., this issue, 1988.

Loeltz OJ., B. Irelan, J.H. Robison, and F.H. Olmsted, Geohydrologic Reconnaissance of the Imperial Valley, California. U.S. Geol. Survey Prof, Paper 486-K, 1975.

McDowell S.D., The Salton Sea Scientific Drill Hole in Context. Abs., EOS Trans. AGU, 68, 44, 1987.

McDowell S.D., and W.A. Elders, Authigenic layer silicate minerals in borehole Elmore \#1, Salton Sea Geothermal Field, Califomia, U.S.A. Contr. Mineral. Petrol., 74, 293-310, 1980.

McDowell S.D., and W.A. Elders, Allogenic layer silicate minerals in borehole Elmore \#1, Salton Sea Geothermal Field, California. Am. Mineral., 68, 1146-1159, 1983.

McKibben M.A., and W.A. Elders, Fe-Zn-Cu-Pb mineralization in the Salton Sea geothermal system, Imperial Valley, California. Econ. Geol., 80, 539-559, 1985.

McKibben M.A., and C.S. Eldridge, Sulfur isotope variations among minerals and fluids in the Salton Sea Geothermal System. Am. Jour. Sci. (submitted), 1988.

McKibben M.A., A.E. Williams, W.A. Elders, and C.S. Eldridge, Saline brines and metallogenesis in a modern sediment-filled rift: The Salton Sea geothermal system, California, U.S.A. Applied Geochemistry, in press, 1987.

McKibben M.A., J.P. Andes, Jr., and A.E. Williams, Active ore-formation at a brine interface in metamorphosed deltaic-lacustrine sediments: The Salton Sea geothermal system, Califomia. Econ. Geol., in press, 1988a.

McKibben M.A., A.E. Williams, and S. Okobo, Metamorphosed Plio-Pleistocene evaporites and the origins of hypersaline brines in the Salton Sea geothermal system, California: Fluid inclusion evidence. Geochim. Cosmochim. Acta, 52, in press, 1988 b.

Meidav T., and J.H. Howard, An update of tectonics and geothermal resource magnitude of the Salton Sea Geothermal Field. Trans. Geothermal Resources Council, 3, 445-448, 1979.

Merriam R., and O.L. Bandy, Source of the upper Cenozoic sediments in Colorado River Delta Region. J. Sed. Pet. 35, 911-916, 1965.

Merriam R., and J.L. Bischoff, Bishop Ash: A widespread volcanic ash extended to southern Califomia. J. Sed. Pet., 45, 207-211, 1975.

Michels D.E., A chemical method for measuring steam quality in two-phase flowlines. Trans. Geothermal Resources Council, 10, 443-445, 1986a.

Michels D.E., SSSDP fluid compositions at first flow test of State 2-14. Trans. Geothermal Resources Council, 10,461-466, 1986b.

Michels DE., Salinity stabilization for non-advecting brine in a temperature gradient. J. Geophys. Res., this issue, 1988.

Moore D.G., Plate edge deformation and crustal growth, Gulf of California structural province. Bull. Geol. Soc. Am., 84, 1883, 1973.

Muffler L.J.P., and B.R. Doe, Composition and mean age of detritus of the Colorado River delta in the Salton Trough, southeastem Califomia. Sediment. Petrol., 38, 384-399, 1968. 
Muffler L.J.P., and DE. White, Active metamorphism of upper Cenozoic sediments in the Salton Sea Geothermal Field and the Salton Trough, southeastern California. Geol. Soc. Am. Bull., 80, 157-182, 1969.

Newmark R.L., P.W. Kasameyer, L.W. Younker, and P.C. Lysne, Research drilling at the Salton Sea geothermal field, Califomia: The shallow thermal gradient project. EOS Trans. AGU, 67, 698-707, 1986.

Newmark R.L., P.W. Kasameyer, and L.W. Younker, Shallow Drilling in the Salton Sea Region. J. Geophys. Res., this issue, 1988.

Nicholson R.W., Extensive coring in deep hot geothermal wells. Trans. Geothermal Resources Council, $10,467-472,1986$.

Olson E.R., and J.S. Matlick III, A flow through model for the Westmoreland geothermal system, Imperial Valley, Califomia. UCR-IGPP Rep. 78/7. Inst. Geophys. and Planet. Phys., Univ. of California, Riverside, 1978.

Paillet F.L., (editor) Preliminary report on geophysical well-logging activity on the Salton Sea Scientific Drilling Project, Imperial Valley, California. U.S. Geol. Surv., Open-file Report 86-544, 99 pp., 1986.

Paillet F.L., and R.H. Morin, Analysis of Geophysical well logs obtained in the State 2-14 borehole, Salton Sea Geothermal Area, California. J. Geophys. Res.; this issue, 1988.

Pourade R.F., Anza Conquers the Desert. Copley Press, Inc., San Diego, 216 pp. 1971.

Rex R.W., The origin of the brines of the Imperial Valley, California. Trans. Geothermal Resources Council, 7, 321, 1983.

Riney T.D., J.W. Pritchett, and S.K. Garg, Salton Sea Geothermal Field reservoir simulations. Trans. Geothermal Resources Council 2, 2571-574, 1978.

Robinson P.T., W.A. Elders, and L.J.P. Muffler, Quaternary volcanism in the Salton Sea geothermal field, Imperial Valley. Geol. Soc. Amer. Bull., 80, 157-182, 1976.

Roedder E., and K.W. Howard, Fluid inclusions in SSSDP Core: Preliminary Results. J. Geophys. Res., this issue, 1988.

Sass J.H., and W.A. Elders, Salton Sea Scientific Drilling Project: Scientific program. Trans. Geothermal Resources Council, 10, 473-478, 1986.

Sass J.H., S.S. Priest, L.E. Duda, C.C. Carson, J.D. Hendricks, and L.C. Robison, Thermal regime of the State 2-14 Well, Salton Sea Scientific Drilling Project. J. Geophys. Res., this issue, 1988.

Schiffman P., W.A. Elders, A.E. Williams, S.D. McDowell, and D.K. Bird, Active metasomatism in the Cerro Prieto geothermal system, Baja California, Mexico: A telescoped low P/T metamorphic facies series. Geology, 12, 12-15, 1984.

Skinner B.J., D.E. White, H.J. Rose, and R.E. Mays, Sulfides associated with the Salton Sea geothermal brine. Econ. Geol., 62, No. 3, 316-330, 1967.

Shearer C.K., JJ. Papike, S.B. Simon, BL. Davis, and F.J. Rich, Mineral Reactions in altered sediments from the California State 2-14 Well: Variations in the modal mineralogy, mineral chemistry and bulk composition of the SSSDP core. J. Geophys. Res., this issue, 1988.

Shoemaker E. (ed) Continental Drilling, report, 56 pp., Carnegie Inst. of Washington, D.C., 1974.

Solbau R., O. Weres, L. Hansen, and B. Dudak, Description of a high temperature downhole fluid sampler. Trans. Geothermal Resources Council, 10, 479-484, 1986.

Stehli F.G. and R.S. Andrews, The United States Continental Scientific Drilling Program, in Observations of the Continental Crust Through Drilling II., edited by Behr, H-J., and F.G. Stehli, Springer-Verlag, Berlin, 229 pp., 1987.

Sturtevant R.G., and A.E. Williams, Oxygen isotopic profiles of the State 2-14 geothermal well: evidence for a complex thermal history. EOS Trans. AGU, 68, 445, 1987.

Tarbet L.A., and W.H. Holman, Stratigraphy and micropaleontology of the west side of the Imperial Valley, California. Am. Assoc. Petroleum Geologists Bull., 28, $1781,1944$.

Tarif P.A., R.H. Wilkens, and C.H. Cheng, Untrasonic velocities and scanning electron microscope studies of Cores from State 2-14 borehole, Imperial Valley, Califomia. J. Geophys. Res., this issue, 1988.

Thompson J.M., and R.D. Foumier, Chemistry and geothermometry of brine produced from the Salton Sea Scientific Drill Hole, Imperial Valley, Califomia. J. Geophys. Res., this issue, 1988. 
Towes D., An estimation of the Geothermal Energy Resource in the Salton Trough. Rep. UCRL-51851, Lawrence Livermore Laboratory, Univ. of California, 1976.

Turner FJ., Metamorphic Petrology: Mineralogical and Field Aspects. McGraw Hill Book Co., New York, 403 pp., 2nd edition, 1986.

U.S. Geodynamics Committee, Continental Scientific Drilling Program. U.S. Geodynamics Committee, National Academy of Sciences, 150 pp., 1979.

White DE., Environments of generation of some base-metal ore deposits. Econ. Geol. 63, 301-335, 1968.

White D.E., E.T. Anderson, and D.K. Grubbs, Geothermal brine well: Mile deep hole may tap ore-bearing magmatic water and rocks undergoing metamorphism. Science 130,919-922, 1963.

Williams A.E. and M.A. McKibben, A brine interface in the Salton Sea geothermal system, California: Fluid geochemical and isotopic distribution. UCR-IGPP Rep. 87/31, Inst. Geophys. and Planet. Phys., Univ. of California, Riverside, 66 pp., 1987.

Winker C.D., Neogene stratigraphy of the Fish Creek-Vallieto Section, southern California: Implications for early history of the northem Gulf of California and Colorado Delta. Unpublished Ph.D. Dissertation, Univ. of Arizona, Tucson 1987.

Wolfenbarger F.M., Battery pack/controller for high temperature applications. Trans. Geothermal Resources Council, 10, 485-489, 1986.

Van de Kamp P.C., Holocene continental sedimentation in the Salton basin, Califomia: A reconnaissance. Bull. Geol. Soc. Am., 84, 827-848, 1973.

Yi Z., On the shallow hydrothermal regime of the Salton Sea geothermal Field, Califomia. UCR-IGPP Rep. 87/45, M.S.Thesis, Inst. Geophys. and Planet. Phys., Univ. of Califomia, Riverside, 265 pp., 1987.

Younker L., P.W, Kasameyer, and J.D. Tewhey, Geological, geophysical and thermal characteristics of the Salton Sea geothermal field, California. J. Volcan. Geothermal. Res., 12, 221-258, 1982.

Zukin J.G., D.E. Hammond, T.-L. Ku, and W.A. Elders, Uranium-thorium series radionuclides in brines and reservoir rocks from two deep geothermal boreholes in the Salton Sea Geothermal Field, Southeastem Califomia. Geochim. et Cosmochim. Acta 51, 2719-2731, 1987. 